\title{
Bilişsel Psikoloji Bakış Açısından Sosyal Etkileșimin Toplumsal Bellek Üzerindeki Rolü
}

\section{Role of Social Interaction in Collective Memory from the Perspective of Cognitive Psychology}

\author{
Aysu Mutlutürk ${ }^{1}$ (1)
}

Yazar notu: Bu makalenin ilk versiyonu üzerindeki yorum ve önerileri için Ali i . Tekcan, Hasan G. Bahçekapılı ve Hande Gündoğan'a teşekkürler.

'Dr., İstanbul Medipol Üniversitesi, İnsan ve Toplum Bilimleri Fakültesi, Psikoloji Bölümü, İstanbul, Türkiye

\section{ORCID: A.M. 0000-0002-5217-3021}

\section{Sorumlu yazar/Corresponding author: \\ Aysu Mutlutürk, \\ İstanbul Medipol Üniversitesi, İnsan ve \\ Toplum Bilimleri Fakültesi, Psikoloji Bölümü, İstanbul, Türkiye \\ E-posta/E-mail: amutluturk@medipol.edu.tr}

Başvuru/Submitted: 29.08.2019 Revizyon Talebi/Revision Requested: 03.09.2019

Son Revizyon/Last Revision Received:

02.12.2019

Kabul/Accepted: 13.01.2020

Online Yayın/Published Online: 16.11 .2020

Atıf/Citation: Mutluturk, A. (2020). Bilişsel psikoloji bakış açısından sosyal etkileşimin toplumsal bellek üzerindeki rolü. Psikoloji Çalıșmaları - Studies in Psychology, 40(2): 285-316.

https://doi.org/10.26650/SP2019-0063
ÖZ

Toplumsal bellek, sosyal bilimlerin sosyoloji, tarih, antropoloji ve siyaset bilimi gibiçeşitli disiplinlerinde kapsamlı biçimde çalışılmıştır. Bu durum, terim hakkında çok çeşitli tanımlamaların ortaya çıkmasıyla sonuçlanmıştır. Toplumsal belleğin disiplinler arasında kabul gören bir tanımı olmasa da terimin tüm kullanımlarını bağlayan ortak zemin, toplumsal belleğin bir grup tarafından paylaşılan, sosyal bağlam ya da kültürel ürünler tarafından yeniden şsekillendirilen ve grup üyelerinin sosyal kimliği üzerinde önemli rolü olan bir bellek formu olmasıdır. Bellek süreçleri, psikologların temel ilgi alanlarından biridir. Ancak ilginç bir biçimde, toplumsal belleğin sorularının psikoloji alanında sistematik olarak araştırılmasına henüz yeni başlanmıştır. Bu derlemenin amacı, bilişsel psikoloji alanındaki deneysel çalışmalardan elde edilen bulguların toplumsal belleğin sorularına uygulanmasıdır. $\mathrm{Bu}$ derleme özellikle sosyal etkileşimin belleğin yeniden yapılandırılmasındaki ve farklı bireylerin bellek temsillerinin birbirine yakınsayarak ortak bir geçmiş temsiline dönüşmesindeki rolüne yönelik deneysel çalışmalara odaklanmaktadır. Deneysel ortamda gerçek yaşamın basitleştirilmiş simülasyonlarını oluşturan bu çalışmalar, belleğin sosyal bulaşıcılığı, ortaklaşa hatırlama, sosyal bağlamda seçici hatırlama ve hatırlamaya bağlı unutma gibi paradigmaların toplumun ortak anılarının oluşumu ve hatırlanmasının altında yatan bilişsel mekanizmaların bir temsili olabileceğini ileri sürer. Derleme, bu çalışmaları inceledikten sonra, toplumsal bellek üzerine gerçekleştirilen deneysel ve betimleyici çalışmaların bulguları arasındaki paralelliklere odaklanacaktır. Derleme, son olarak, laboratuvar ortamındaki deneysel çalışmaların, toplumsal olaylara ilişkin anıların oluşumu ve hatırlanmasına yönelik genel prensipler sunarak, toplumsal belleğin altında yatan bilişsel mekanizmaların anlaşılmasına ilişkin katkı sunabileceği görüşüyle sonlanacaktır. Bu derleme, bilişsel psikoloji bakış açısını benimsemekle birlikte, çeşitli disiplinlerin farklı anlayışlarını harmanlayarak toplumsal bellek çalışmalarında disiplinler arası bir yaklaşımı teşvik etmeyi ve toplumsal belleğin daha iyi anlaşılmasına katkıda bulunacak yeni araştırma sorularına yön vermeyi ümit etmektedir.

Anahtar Kelimeler: Toplumsal bellek, bilişsel psikoloji, toplumsal olay, deneysel psikoloji, sosyal etkileşim, yapılandırıcı bellek 


\section{ABSTRACT}

Collective memory has been studied extensively in various disciplines of the social sciences, such as sociology, history, anthropology, and political science, resulting in various definitions for the term. Although there is not a well-accepted conceptualization for collective memory across disciplines, the common ground that binds all uses of the term is that collective memory is a form of memory shared by a group, reshaped by social artifacts, and that has an important role in the social identity of the group's members. Memory processes have been of central interest to psychologists. However, systematic investigation of the issues in collective memory from a psychological perspective has just begun. The review aims to apply the findings obtained from experimental studies in cognitive psychology to the issues in collective memory. This review focuses on the experimental studies on the role of social interaction in the reconstruction of memories and convergence among individuals on a shared representation of the past. The studies in experimental settings have generated simplified simulations of real life and suggest that social contagion of memory, collaborative recall, selective retrieval, and retrieval-induced forgetting in social contexts may represent cognitive mechanisms underlying the formation and retrieval of collective memories. After exploring these studies, the review focuses on the parallels between the experimental and exploratory studies on collective memory. Finally, the conclusion proposes that studies in the lab setting can contribute to understanding cognitive mechanisms underlying collective memories in real life, providing general principles to predict collective memories' formation and maintenance. Although this review adopts a cognitive psychological perspective, it attempts to blend insights from various approaches, to encourage an interdisciplinary approach to studying collective memory and devise new research questions to improve the understanding of collective memory.

Keywords: Collective memory, cognitive psychology, public event, experimental psychology, social interaction, reconstructive memory

\section{EXTENDED ABSTRACT}

Collective memory is widely discussed but poorly understood. This notion has been studied in various social sciences, such as sociology, history, anthropology, and political science, and recently embraced by psychology, which is surprising because memory is one of the central concerns in the field of psychology (Coman, Brown, Koppel, \& Hirst, 2009a; Hirst \& Echterhoff, 2008; Hirst \& Manier, 2008). In this review, the study of collective memory is discussed from a psychological perspective. The aim is to apply the findings obtained from experimental studies in cognitive psychology to the issues of collective memory. In particular, this review explores the experimental studies on the role of social interaction in the reconstruction of memories and convergence among individuals on a shared representation of the past.

The review has four major parts. The first part discusses the conceptual oppositions in the field of collective memory research. One reason for the scarcity of collective memory studies within the discipline of psychology may be absence of a commonly accepted definition of the term across the fields of the social sciences. Until recently, social scientists have tended to treat collective memory as social representations not in the mind but in the world, such as cultural symbols, practices, archival records, and commemorations (Harris, Paterson, \& Kemp, 2008; Hirst \& Manier, 2008; Wertsch, 2002). Notably, from the psychological perspective, the agent of remembering is the individual and collective memory is represented in individuals' 
minds (See Hirst \& Manier, 2008). A reconciling view is that collective memory is a form of memory shared by a group, reshaped by social artifacts, and that has an important role in the social identity of the group's members (Coman et al., 2009a; Roediger \& Abel, 2015).

The second part reviews the research on the reconstructive nature of human memory. Evidence has demonstrated that individuals may remember a story by reorganizing it based on existing schema (Bartlett, 1932/1995) and then mistakenly recall words that were highly typical category members but that did not exist in the given word list (Roediger \& McDermott, 1995) and modify their memories of an event when post-event misleading information is provided (Chrobak \& Zaragoza, 2008; Loftus, Miller, \& Burns, 1978; Loftus \& Palmer, 1974; Loftus \& Zanni, 1975; Zaragoza \& Mitchell, 1996).

After reviewing the research suggesting that individuals remember past events by reconstructing them rather than copying them in an accurate form, the third part explores how individuals reconstruct their memories through social interaction and come to share similar renderings of the past. Research on the reconstructive nature of collective memories employs various paradigms to understand how individual memories are transformed into shared memories (Barnier, Sutton, Harris, \& Wilson, 2008; Hirst \& Echterhoff, 2012; Stone, Coman, Brown, Koppel, \& Hirst, 2012). For instance, some studies have demonstrated how one individual implants misleading memories into others' minds in a conversational setting by using the social contagion paradigm (e.g., Meade \& Roediger, 2002; Roediger, Meade, \& Bergman, 2001). Employing a socially shared retrieval-induced paradigm, some studies have demonstrated how selective retrieval of memories by a speaker lead both the speaker and the listener to forget unmentioned memories (e.g., Coman \& Hirst, 2011; Coman, Manier, \& Hirst, 2009b; Cuc, Ozuru, Manier, \& Hirst, 2006; Cuc, Koppel, \& Hirst, 2007). Other studies, using collaborative recall and inhibition paradigm, have presented evidence on how individuals remember more in a group than they might when remembering alone, but less than the sum of the potential of all individuals in the group (e.g., Congleton \& Rajaram, 2011; Rajaram \& Pereira-Pasarin, 2007; Yaron-Antar \& Nachson, 2006). These studies suggest that social contagion, selective retrieval, and retrieval-induced inhibition in social contexts may represent cognitive mechanisms underlying the formation and maintenance of collective memories.

Based on this idea, the fourth part reviews studies on how individuals remember public events; hence, it explores the relation of the laboratory studies to the studies that have investigated changes in the content of collective memories (e.g., Coman, Stone, Castano, \& Hirst, 2014; Coman \& Hirst, 2015; Hirst et al., 2009) and the retrieval patterns of collective memories within and across groups (e.g., Corning, Gaidys, \& Schuman, 2013; Schuman \& Rodgers, 2004; Tekcan, Ece, Gülgöz, \& Er, 2003). 


\section{Discussion}

Overall, this paper reviews the parallels between experimental and exploratory studies on collective memory and concludes that understanding cognitive mechanisms of how individual memories are transformed into shared memories in the lab setting would provide general principles to predict the formation and maintenance of collective memories in real life. Although the review adopts a cognitive psychological perspective, it attempts to blend insights from different approaches, to encourage an interdisciplinary approach to studying collective memory and devise new research questions to improve the understanding of collective memory. 
Toplumsal bellek kavramı, Halbwachs'ın (1950/1980) 20. yüzyılın başlarındaki çalışmalarından bugüne sosyoloji, tarih, siyaset bilimi ve antropoloji gibi disiplinlerin ilgisini çekmiştir. Buna karşılık, temel ilgi alanlarından biri bellek süreçleri olan psikoloji disiplininde toplumsal bellek konulu sistematik çalışmalar son 20 yıllık dönemde yoğunlaşmıştır. Çeşitli disiplinlerin toplumsal belleğin nasıl tanımlanacağı ve inceleneceğine ilişkin farklı bakış açıları benimsemeleri, psikolojinin bireysel bellek süreçlerine ilişkin yerleşik kavram, yöntem ve bulgularının toplumsal belleğin altında yatan mekanizmaları anlamak için kullanılmasını geciktirmiş olabilir (Coman, Brown, Koppel ve Hirst, 2009a). Toplumsal belleğin tanımına yönelik disiplinler arası tartışma konularından biri, toplumsal bellek ve tarihin birbirinden nasıl ayrıştırılacağıdır (Hirst ve Manier, 2008; Olick, 1999; Wertsch ve Roediger, 2008). Tarih ve toplumsal bellek ayrımına değinen kuramsal çalışmalar, geçmişe ilişkin bu iki temsil biçiminin farklı amaçları olduğunu vurgulamaktadır (Bilgin, 2013; Halbwachs, 1950/1980; Novick, 1999; Páez, Bellelli ve Rimé, 2009; Páez ve Liu, 2010; Wertsch ve Roediger, 2008). Buna göre, tarih disiplininin topluluğun ortak değerlerini yansıtan bir toplumsal kimlik inşasına ve bunun tutarlılığını korumaya yönelik bir amacının olmadığı, tarihsel bilgi ve bulgulara bağlı kaldığı ve elde ettiği yeni bulguların izinde var olan anlatıyı güncellediği belirtilmektedir. Toplumsal belleğin ise öncelikli olarak toplumsal kimliğin inşası ve tutarlıl1ğını koruma amacına hizmet ettiği ve bu amaca uygun biçimde tarihsel bilgiyi de yeniden yapılandırabildiği vurgulanmaktadır. Toplumsal belleğin tanımına ilişkin bir diğer tartışma konusu ise toplumun ortak geçmişinin nerede temsil edildiği ve toplumsal belleği ele alırken kişisel bellek temsillerinin hesaba katılıp katılmayacağıdır. Sosyoloji ve siyaset bilimi gibi toplumsal belleği kültürel çerçevede ele alan disiplinler, toplumun ortak geçmişinin bireyin zihninin dışında, örneğin gelenek ve mitler, anma törenleri, müzeler ve anıtlar gibi kültürel ürünlerde temsil edildiğini ileri sürer (Assmann, 1995; Irwin-Zarecka, 1994; Olick, 1999; Olick ve Robbins, 1998). Öte yandan, toplumsal belleği psikoloji perspektifinden ele alan araştırmacılar, toplumsal geçmişe ilişkin bilgilerin işlenmesi, amaca uygun şekilde yapılandırılarak depolanması ve geri çağrılması gibi süreçlerin bireyin zihninde gerçekleştiğini vurgularlar (Hirst ve Manier, 2008; Wertsch ve Roediger, 2008). Bu yaklaşımı benimseyen araştırmacılar, bireyin zihnindeki temsilleri hesaba katmadan bireysel ya da toplumsal herhangi bir bellek sürecinin anlaşılmasının mümkün olamayacağını belirtmektedirler (Hirst ve Manier, 2008; Wertsch ve Roediger, 2008). 
Son yıllarda bu farklı bakış açılarının ortak bir zeminde buluşmaya yöneldiği ve özellikle bilişsel psikoloji alanı içinde, toplumsal belleğin 'bireysel anıların ve bilgilerin paylaşılan bir özeti’ şeklinde tanımlanması üzerinde fikir birliğine yaklaşıldığı söylenebilir (Harris ve ark., 2008; Hirst, Manier ve Cuc, 2003; Mutlutürk, Boduroğlu ve Tekcan, 2018). Bu ortak kavramsal zeminde, toplumsal bellek toplumu oluşturan bireylerin ve bireylerle kültürel ürünlerin arasında kurulan bir ağa benzetilir (Hirst ve Manier, 2008; Olick, 1999; Wertsch, 2002; Wertsch ve Roediger, 2008). Bilişsel bilimler ve psikolojide yaygın olarak incelenen A $\breve{g}$ Kuramı (Network Theory), dağılımlı işlem (distributed processing) ve dağılımlı bellek (distributed memory) modellerine dayanan bu benzetmeye göre, toplumsal belleğin oluşabilmesi için bir olay hakkında hatırlanan bilgi ve deneyimlerin bireyler arasında aktarılması ve topluluk içinde dağılıp yayılması gerekir (Hirst ve Manier, 2008; Mutlutürk ve ark., 2018; Olick, 1999; Páez ve Liu, 2010; Wertsch, 2002). Bu bireysel bilgi ve deneyimler birbirinden bağımsız biçimlerde kodlanıp temsil ediliyor olabilir, fakat topluluk üyeleri arasındaki aktarım sırasında bu farklı anılar birbirleriyle ve diğer kültürel ürünlerle etkileşime girer ve yeniden yapılandırılır. Bu etkileşim sonucunda, paylaşılan anılar (shared memories), farklı bireysel anıların toplamının ötesinde, toplumsal bellek olarak nitelediğimiz bir bellek formu haline gelir (Hirst ve Manier, 2008; Stone ve Jay, 2019; Wertsch ve Roediger, 2008).

Toplumsal belleğin bireysel anıların paylaşılan bir özeti olduğu tanımından yola ç1kan araştırmacılar, psikolojinin kişisel belleğe ilişkin kuram ve yöntemlerinin toplumsal belleği anlamak için kullanılabileceği görüşündedirler (bkz. Hirst ve Manier, 2008). Özellikle, bireysel ve grup halinde hatırlamanın hatırlanan bilgilerde farklılık yaratıp yaratmadığı ve sosyal etkileşim durumunda (örn., bir sohbet ortamında ya da geleneksel ve yeni medya yoluyla) bireyler tarafından geri getirilen farklı bilgilerin zaman içinde birbirine yakınsayarak (mnemonic convergence) ortak bir belleğe dönüşüp dönüşmediği yönündeki sorulara yanıt aramaktadırlar. Elde edilen bulgular, toplumsal belleğin oluşumunun ve toplumsal bellek temsillerinin altında yatan bilişsel mekanizmaların anlaşılmasına ve bu mekanizmaların toplum içindeki diğer sosyal ve kültürel süreçlerle ilişkisinin ortaya konmasına katkı sağlamaktadır (örn., Coman ve Hirst, 2015; Coman, Stone, Castano ve Hirst, 2014; Yaron-Antar ve Nachson, 2006).

$\mathrm{Bu}$ derlemenin amacı, sosyal etkileşimin bellek süreçlerindeki rolünü inceleyen deneysel çalışmaları özetlemek ve bu çalışmaların toplumun geçmişine ilişkin ortak bir bellek oluşmasının altında yatan mekanizmaları anlamamıza yönelik katkılarını değer- 
lendirmektir. $\mathrm{Bu}$ amaçla, ilk olarak yeniden yapılandırıcı bellek (reconstructive memory) süreçlerine değinilecektir. Ardından bireylerin sosyal etkileşim yoluyla aynı olaya ilişkin farklı detaylar içeren bireysel anılarını yeniden yapılandırabildiklerini ve böylece bu bireysel anıların birbirine benzeşip yakınsayarak bir ortak belleğe dönüşebildiğini ortaya koyan deneysel paradigmalar ile bu paradigmalardan elde edilen bulgular özetlenecektir. Bu aşamada, belleğin sosyal etkileşim yoluyla yeniden yapılandırılarak bir ortak belleğe dönüşmesi sürecini etkileyen çeşitli faktörler de ele alınacaktır. Son olarak, deneysel ve betimleyici araştırma bulguları arasındaki paralellikler ortaya konularak, deneysel bulguların toplumsal belleğin altında yatan bilişsel mekanizmaların anlaşılmasına katkıları değerlendirilecektir.

\section{Yapılandırıcı Bellek}

Bir topluluğu oluşturan bireyler tarafından geri getirilen farklı bilgilerin, zaman içinde birbirlerine benzeşip yakınsayarak topluluğun ortak belleğine dönüşmesi olasılığından söz edebilmek için öncelikle belleğin olayları olduğu gibi kaydeden bir sistem mi yoksa yapılandırılan bir sistem mi olduğunu anlamak gerekir. İnsanların geçmişi birebir kopyalayarak değil, gerek içsel bilgi ve deneyimler gerekse çevresel/dişsal faktörlerle yeniden yapılandırarak hatırlıyor olabileceğini gösteren bulgular vardır. Bu derlemenin asıl konusu olan toplumsal belleğin sosyal bağlamda yapılandırılmasına ilişkin çalışmalar için bir arka plan oluşturmak bakımından bu bulgulara kısaca değinmek anlamlı olacaktır.

Belleği anlam, önceki bilgiler, deneyimler ya da sosyal etkileşim gibi faktörlerden bağımsız ve geçmişi birebir kaydeden bir kayıt cihazı gibi ele alan bakış açısı 20. yüzyılın ortalarında değişmeye başlamıştır (Koriat, Goldsmith ve Pansky, 2000; Surprenant ve Neath, 2009). İnsanların geçmişteki bilgileri hatırlarken bunları yeniden yapılandırdıklarını öne süren ilk araştırmacılardan biri olan Bartlett (1932/1995), İngiliz katılımc1lardan K1zılderili kültürüne özgü konular ve tabirler içeren bir hikayeyi (Hayaletlerin Savaş1/The War of Ghosts) daha sonra hatırlamak üzere okumalarını istemiş ve hikayeyi nasıl hatırladıklarını incelemiştir. Katılımcılar, genellikle hikayeyi basitleştirmiş, bazı detayları hikayenin orijinal haline kıyasla daha fazla vurgulamış ve bazı kısımları değiştirerek kendi kültürleriyle uyumlu hale getirmişlerdir. Örneğin hikayede geçen ve kendi kültürlerinde aşina olmadıkları "fok balığı avlama" aktivitesini, hikayeyi anlatırken "balık tutma" gibi aşina oldukları bir aktivite ile değiştirmişler, doğa üstü olayları rasyonalize etmişler ya da anlatılarına dahil etmemişler ve yine kendi kültürlerinde karşılaş- 
madıkları isimlere (örn., Egulac) anlatılarında yer vermemişlerdir. Bir başka deyişle, katılımcılar hikayeyi orijinalinin birebir kopyası olarak değil, zihinsel şemalarına ve kültürel normlara göre yeniden yapılandırarak hatırlamışlardır (Bartlett, 1932/1995).

Bellek temsillerinin yeniden yapılandırılan bir sürecin sonucu olabileceği konusu 1970'li yıllar itibariyle yeniden gündeme gelmiştir. Bu alanda yapılan deneysel çalışmaların bir kolu, belleğin önceki bilgiler, şemalar, deneyimler, beklentiler ve çıkarımlar gibi faktörlerle yönlendirilen yapılandırıcı bir sürecin sonucu olabileceğine odaklanmıştır (bkz. Brewer ve Treyens, 1981; Marsh, Cook ve Hicks, 2006; Roediger ve McDermott, 1995). Örneğin, insanlar kısa bir süre bulundukları bir ofiste hangi eşyaları gördüklerini hatırlarken bir ofis ortamı hakkında var olan bilgileri doğrultusunda çıkarımlar yapmışlar ve farkında olmadan bellek yanılsamasına düşerek, aslında ofiste görmemiş oldukları eşyaları da gördüklerini belirtmişlerdir (Brewer ve Treyens, 1981). Benzer şekilde, örneğin, yastık, yatak, çarşaf, yorgan, rüya gibi kelimeler içeren bir kelime listesi üzerinde çalıştıktan sonra, listede olmayan ama listedeki kelimeleri içeren kategorinin güçlü bir temsilcisi olan $u y k u$ kelimesinin listede yer aldığını hatırlama eğilimi göstermişlerdir (Roediger ve McDermott, 1995).

Yapılandırıcı bellek üzerine yürütülen araştırmalar, insanların sadece içsel bilgi ve deneyimleri ile değil, bazı çevresel/dışsal faktörlerle de belleği yeniden yapılandırabildiklerini göstermiştir. Örneğin "olay sonrası yanlış bilgi paradigması” adlı bir yöntemle gerçekleştirilen bir dizi araştırma, yanlış yönlendirmeler ve çarpıtmalar içeren soruların görgü tanı̆̆ı belleğinde yanılsamalara neden olabileceğini göstermiştir (Loftus ve Palmer, 1974; Loftus ve Zanni, 1975; Loftus ve ark., 1978). Pek çok araştırmacı tarafından tekrarlanan bu bulgular, geçmişte deneyimlenen olaylar hakkındaki yeni veya çarpıtılmış bir bilginin insanların o olayı nasıl hatırladığını değiştirip dönüştürebildiğini göstermektedir (örn., Alpar, Er ve Uçar Boyraz, 2007; Belli, Lindsay, Gales ve McCarthy, 1994; Chrobak ve Zaragoza, 2008; Drivdahl ve Zaragoza, 2001; Er, Alpar ve Uçar, 2005; Mitchell ve Zaragoza, 1996; 2001).

Özetle, günümüz bellek araştırmaları bilişsel şemalar, önceki bilgiler gibi içsel faktörlerin veya olay sonrası maruz kalınan yeni bilgiler gibi çevresel faktörlerin etkisiyle olaylar hakkındaki bilgi ve deneyimlerimizi yeniden yapılandırarak hatırladığımıza ilişkin güçlü bulgular sunmaktadır (bkz. Mısırlısoy ve Ceylan, 2014). Yukarıda değinilen çalışmalarda kişilerin maruz kaldığı yönlendirici bilgilerin kaynağı çoğunlukla bilgisa- 
yar aracılığıyla ya da kağıt üzerinde sunulan uyaranlardır (örn., filmler, fotoğraflar, kelime listeleri). Belleğin yeniden yapılandırılmasına yönelik araştırmaların bir başka kolu ise bu yaklaşımın ötesine geçerek, bir diğer katılımcı ya da araştırmadaki işbirlikçinin (confederate) hatırladığı bilgileri de işin içine katmıştır (örn., Congleton ve Rajaram, 2011; Cuc, Koppel ve Hirst, 2007; Roediger, Meade ve Bergman, 2001). Böylece belleğin toplumsal bağlamdaki sosyal etkileşim yoluyla yeniden yapılandırılma süreçlerini deneysel yöntemlerle inceleme olanağı bulunmuştur.

\section{Sosyal Etkileşimin Belleğin Yeniden Yapılandırılması Üzerindeki Rolü}

Belleğin yapılandırılmasında sosyal etkileşimin rolüne odaklanan deneysel çalışmalar (örn., Coman ve Hirst, 2012; 2015; Congleton ve Rajaram, 2011; Cuc ve ark., 2007; Roediger ve ark., 2001), bu sürecin altında yatan mekanizmaları bireylerin bir grup içinde birbirleriyle iletişim halinde oldukları bir tür sohbet ortamı simülasyonu içinde inceleme yoluna gitmişlerdir. Bu sayede, bireylerin bellekten geri getirdikleri bilgilerle birbirlerinin belleğini karşılıklı olarak nasıl şekillendirdiklerini anlamayı amaçlamışlardır. Belleğin sosyal etkileşim sürecinde yeniden yapılandırıldığı ve bunun bir sonucu olarak farklı bellek temsillerinin birbirine yakınsayıp ortak bir geçmiş temsiline dönüştüğü varsayımından hareket eden bu çalışmalar, kullandıkları deneysel paradigmalar bazında ayrı başlıklar altında incelenecektir.

Belleğin Sosyal Bulaşıcılığı. Belleğin sosyal bulaşıcılığı (social contagion of memory), kişilerin geçmişe ilişkin kendi hatırladıklarıyla başkalarının hatırladıklarını birleştirerek belleklerini yeniden yapılandırmaları ve böylece bilgi ile deneyimlerin kişiler arasında yayılması anlamına gelir (Hirst ve Echterhoff, 2012; Meade ve Roediger, 2002; Roediger ve ark., 2001). Loftus ve arkadaşlarının (örn., Loftus ve Palmer, 1974; Loftus ve Zanni, 1975) olay sonrası yanlış bilgi paradigması ile Asch'in (1956) sosyal uyum çalışmalarından ilham alan belleğin sosyal bulaşıcılığı paradigması genellikle üç aşamadan oluşur. İlk aşamada, katılımcı uyaranları (örn., bir dizi fotoğrafı) araştırmacının işbirlikçisiyle birlikte öğrenir. İkinci aşamada, bu uyaranları bazen yanlış detaylar bildiren işbirlikçiyle birlikte hatırlar. Üçüncü aşamada ise katılımcı uyaranları tek başına hatırlar (Roediger ve ark., 2001). Böylece katılımcının işbirlikçi tarafından bildirilen yanlış detayları bireysel hatırlama testi sırasında belirtip belirtmediği, bir başka deyişle, katılımcının sosyal bulaşma yoluyla bellek yanılsaması sergileyip sergilemediği incelenir. Bu paradigmayı kullanarak gerçekleştirdikleri bir çalışmada, Roediger ve arkadaşlar1 (2001), katılımcıları ikişerli gruplar halinde laboratuvara aldılar ve onlara bir evin 
mutfak, banyo gibi bölümlerini gösteren fotoğraflar sundular. Ardından katılımcılara her bir fotoğrafın ismi bellek ipucu olarak verildi (örn., banyo) ve katılımc1lar sırayla bu fotoğraflardaki çeşitli nesneleri hatırlamaya çalıştılar. Aslında iki katılımcıdan biri araştırmacının işbirlikçisiydi ve ortaklaşa hatırlama prosedürü sırasında çoğunlukla fotoğraflarda sunulan bir nesneyi, bazen de hiç sunulmamış bir nesneyi hatırladığını bildirdi. Üçüncü aşamada, katılımcı tek başına tamamlaması gereken bir hatırlama testine alındı ve fotoğraflardaki nesneleri mümkün olduğunca doğru bir biçimde hatırlaması istendi. Yönergelerde hatırlanan nesnelerin doğru olmasının önemi vurgulanmış olmasına rağmen, işbirlikçi katılımcının yanıltıcı yönlendirmeleri doğrultusunda katılımcıların bellek hatalarını sürdürdükleri gözlendi.

Gabbert, Memon ve Allan (2003), belleğin sosyal bulaşıcılığı paradigmasını gündelik yaşama daha benzer kı1mak için bir suç filmini farklı görüş açılarından izleyen katılımcıların birbiriyle tartışabildikleri bellek uyumu (memory conformity) paradigmasını tasarladılar. Bellek uyumu paradigmasında, katılımcılar deneye ikişerli gruplar halinde alındılar. Ancak belleğin sosyal bulaşıcılığı paradigmasından farklı olarak, bu paradigmadaki katılımcıların hiçbiri hatırlama aşamasında planlı olarak yanlış bilgiler bildiren işbirlikçiler değildi. İlk aşamada, katılımcılar grupça aynı bilgileri öğreniyormuş gibi görünseler de, özel bir ekran yardımıyla her bir katılımcı bazı farklı bilgiler öğrendi. Örneğin, ekranın sağında oturan katılımcı, filmdeki kızın kolyesini görebilirken elindeki kitabın adını göremiyordu. Ekranın solunda oturan katılımcı ise kızın kolyesini göremiyor ama kitabın adını görebiliyordu. Böylece katılımcılar, ikinci aşamada suç filminin detaylarını grupça hatırlarken, her biri farklı bilgiler geri getirdiler. Son aşamada ise her bir katılımcı detayları tek başına hatırladı. Sonuç olarak, son aşamada katılımcıların \%71'i orijinal filmde görmedikleri ama grup tartışmasında diğer katılımcı tarafından değinilen detayları hatırladıklarını belirttiler. Ayrıca katılımcıların tümü kendilerine eşlik eden katılımcıyla aynı filmi izlediklerinden emin olduklarını ifade ettiler. Bir başka deyişle, katılımcılar hatalı biçimde hatırladıklarını belirttikleri detayları gördüklerine inanıyorlardı (Gabbert, Memon ve Allan, 2003). Katılımcıların bellek hatalarını diğer katılımcılarla bir aradayken değil de bireysel hatırlama testinde yapmaları ve aslında öğrenmedikleri bilgileri öğrendiklerinden emin olmaları, diğer insanların hatırladıklarına uyum göstermeyi planlı olarak seçmediklerini, diğer insanların hatırladıkları bilgileri farkında olmadan benimseyip kendi belleklerini yeniden yapılandırdıklarını göstermektedir (Gabbert ve ark., 2000; Roediger ve ark., 2001). Katılımcıların kendilerine eşlik 
eden kişinin ikinci aşamada bazı hatalar yapabileceğine ilişkin bir uyarı aldıkları durumda bile, bireysel test aşamasında diğer kişinin daha önceki yönlendirmeleri doğrultusunda bellek hataları yapmaları da bu bulguları destekler niteliktedir (Meade ve Roediger, 2002). İnsanlar başkalarının hatırladıklarını, kendilerinin hatırlamadıkları bilgilerle ilgili tamamlayıcı bir geri bildirim olarak alırlar. Bu bilgilerin hatalı olduğundan habersiz biçimde, örtük (örn., düşünerek) ya da açık (örn., başkalarıyla konuşarak) tekrarlı hatırlamalar eşliğinde bunları içselleştirirler (Meade ve Roediger, 2002; Roediger ve ark., 2001; Roediger, Zaromb ve Butler, 2009). Bunun sonucunda, kaynak izleme hatası yaparak, bu bilgileri kendi deneyimleriymiş gibi hatırlarlar. Bir başka deyişle, bilginin kaynağı başkasının deneyimi de olsa, bunun kendi deneyimleri olduğunu düşünürler (Roediger ve ark., 2001).

Bellekte sosyal bulaşıcılık etkisi, sunulan yanıltıcı bilginin bağlam ve zihinsel şemalarla ne kadar uyumlu olduğuyla da ilişkilidir (Roediger ve ark., 2001). Örneğin, bu etki hatırlama aşamasında verilen bellek ipucu (örn., banyo) ile telkin edilen yanlış bilginin birbirine uyumsuz olduğu koşulda (örn., lens solüsyonu), bunların birbirine uyumlu olduğu koşula kıyasla (örn., sabun) daha az görülür. Ayrıca duygusal bakımdan nötr olan bilgilere kıyasla, duygusal uyarımı yüksek bilgiler için de sosyal bulaşma etkisinin daha zayıf olduğu gösterilmiştir (Kensinger, Choi, Murray ve Rajaram, 2016). ${ }^{1}$ Bu bulgu, bireylerin geçmişteki duygusal olayların detaylarını hatırlarken başkalarının hatırladıklarından daha az etkileniyor olabileceklerine işaret etmektedir. Öte yandan, yanıltıcı bilginin sosyal olmayan bir kaynak (örn., bilgisayar ya da kağıt üzerindeki bir metin) yerine sosyal bir kaynaktan (örn., iletişim kurulan bir kişiden) alınması (Meade ve Roediger, 2002; Gabbert, Memon, Allan ve Wright, 2004), iletişim kurulan kişinin bir yabancı yerine arkadaş (Peker ve Tekcan, 2009), romantik partner (French, Garry ve Mori, 2008) ya da söz konusu bilgi hakkında bir uzman olması (Koppel, Wohl, Meksin ve Hirst, 2014) ve ikiden fazla kişinin bulunduğu bir grupta muhalif kimse olmaması (Walther ve ark., 2002) bellekte sosyal bulaşıcılık etkisinin ortaya çıkma olasılığını arttırmaktadır.

Belleğin sosyal bulaşıcılığg ve bellek uyumunun, bellek içeriğinin doğruluğunu dikkate almaksızın, topluluğun ortak bir bellek oluşturmasına katkıda bulunabilecek bir mekanizmayı ortaya koyduğu düşünülmektedir (Hirst ve Echterhoff, 2012; Roediger ve ark., 2009; Wertsch, 2002). Ayrıca belleğin sosyal bulaşıcılığının bazı durumlarda daha olası

1 Duygusal uyarımı yüksek bilgilerin duygusal değerliğine göre (olumlu ve olumsuz) bir fark gözlemlenmemiştir. 
olduğunu gösteren çalışmalar, topluluktaki bireylerin birbirleriyle ne kadar yakın ya da birbirlerine ne kadar benzer olduklarına dikkat çeker. Buna ek olarak, etkileşim içinde olunan kişilerin bilgi ve uzmanlığına duyulan güvenin topluluğun ortak bir bellek oluşturmasıyla ilişkili olabileceğine işaret eder.

Ortaklaşa Hatırlama. Sosyal bulaşıcılık paradigmasının kullanıldığı araştırmalar, sosyal etkileşim sonucu hatırlanan yanlış bilgilere odaklanır. ${ }^{2}$ Öte yandan sosyal etkileşimin bellek süreçleri üzerindeki rolü söz konusu olduğunda akla gelen bir diğer soru doğru bilgilerin nasıl unutulduğudur. Bu soruya odaklanan araştırmacıların yaygın olarak kullandıkları deneysel paradigmalardan biri ortaklaşa hatırlama paradigmasıdır (collaborative recall paradigm; Weldon ve Bellinger, 1997). Ortaklaşa hatırlama paradigmasının ilk aşamasında, katılımcılardan birtakım uyaranları (örn., kelime listesi) öğrenmeleri ve bunları yalnız ya da grupça hatırlamaları istenir. Daha sonra, tüm katılımcılar aynı uyaranları yalnız hatırlarlar. Tipik olarak, grupça hatırlamanın bellek üzerinde hem ortaklaşa kolaylaştırma (collaborative facilitation) hem de ortaklaşa ketleme (collaborative inhibition) etkisi olduğu gözlemlenir (Harris, Barnier ve Sutton, 2013; Congleton ve Rajaram, 2011; Rajaram ve Pereira-Pasarin, 2007). Ortaklaşa kolaylaştırma, birden fazla kişinin işbirliği ile hatırlanan bilgi miktarının yalnız başına hatırlanan bilgi miktarından daha fazla olmasıdır. Bu kolaylaştırma etkisine ilişkin yaygın olarak kabul gören açıklama, çapraz ipucu (cross-cuing) açıklamasıdır (Hirst ve Echterhoff, 2012). Çapraz ipucu açıklamasına göre, grup üyeleri hatırlama sırasında birbirlerine bellek ipuçları sağlarlar. Birinin hatırladığg bilgi, diğer grup üyelerine henüz hatırlanmamış bir başka bilgi için hatırlamaya dair ipucu olur. Böylece grup, bir üyenin tek başına geri getirebileceğinden daha fazla bilgiyi geri getirebilir (Hirst ve Echterhoff, 2012).

Grup halinde hatırlama bellek performansına bir maliyet de getirebilir; grubun hatırladığ1 toplam bilgi miktarı (ortaklaşa hatırlama/collaborative recall), grup üyelerinin bireysel olarak hatırladıkları örtüşmeyen ${ }^{3}$ bilgilerin toplamından (nominal hatırlama/no-

2 Belleğin sosyal bulaşıcılığı paradigmasının odak noktası hatırlanan yanlış bilgiler olsa da, işbirlikçi katılımcının doğru hatırladığı bilgilerin diğer katılımcıların doğru hatırladığı bilgi miktarını da arttırdığına ilişkin gözlemler yapılmıştır (bkz. Roediger ve ark., 2001). Ancak bunlar, uygun dengeleme koşulları ile incelenmediğinden kesin olmayan gözlemlerdir. Öte yandan, bu kesin olmayan gözlemler, olay sonrası yanlış bilgi paradigmasının kullanıldığı deneyler tarafından desteklenmektedir. Bu deneylerde olay sonrası doğru yönlendiren sorular alan katılımcıların daha sonraki testlerde doğru bildirim yüzdelerinin arttığı görülmektedir (örn., Er, Alpar ve Uçar, 2005; Loftus, Miller ve Burns, 1978).

3 A, B, C, D, E, F, G şeklindeki bir çalışma listesinden 1. katılımcı A, B ve C'yi, 2. katılımcı A ve C'yi, 3. katılımcı A, D ve G’yi hatırlıyorsa, bu üç katılımcı tarafından hatırlanan tüm bilgilerin içinden örtüşenler çıkarılarak nominal hatırlama grubu oluşturulur. Böylece nominal hatırlama A, B, C, D, G şeklinde olur. 
minal recall) az olabilir (örn., Congleton ve Rajaram, 2011; Pereira-Pasarin ve Rajaram, 2011; Weldon ve Bellinger, 1997). Bu etkiye ortaklaşa ketleme adı verilir. Bu etki için yaygın olarak kabul edilen açıklama ise hatırlama bozulması hipotezidir (retrieval disruption hypothesis). Bu hipoteze göre, bir bilgiyi grup ortamında hatırlamaya çalışmak bireysel bellek organizasyonunu ve hatırlama stratejilerini bozar. Grup üyeleri kendileri için verimli olan stratejiyi kullanamadıklarında hatırlama performansları düşer (Basden, Basden, Bryber ve Thomas, 1997; Rajaram ve Pereira-Pasarin, 2010). Böylece ortaklaşa hatırlama aşamasında, grup üyelerinin yalnız oldukları koşula kıyasla hatırladıkları bilgi miktarında azalma olur. Bu da grubun hatırladığı toplam bilgi miktarının, grup üyelerinin bireysel olarak hatırlayabildikleri bilgilerin toplamından az olmasıyla sonuçlanır.

Bilginin tekrarlı biçimde çalışılması ve geri getirilmesi yoluyla bellek organizasyonunun sağlamlaştırılması (Congleton ve Rajaram, 2011; Pereira-Pasarin ve Rajaram, 2011), çalışma ve test aşamaları arasında geçen sürenin görece uzun olması (Congleton ve Rajaram, 2011) ya da ortaklaşa hatırlamanın gerçekleştiği gruptaki kişilerin öğrenilecek materyal konusunda uzman olmaları (örn., uzman pilot; Meade, Nokes ve Morrow, 2009) gibi faktörler, kontrol koşullarına kıyasla ortaklaşa hatırlama düzeyinin artmasına ve ortaklaşa ketleme düzeyinin azalmasına neden olur. Öte yandan dikkatin bölünmesi (Pereira-Pasarin ve Rajaram, 2011) ve gruptaki kişi sayısının artmasının (Basden, Basden ve Henry, 2000) ortaklaşa ketleme düzeyini arttıran faktörler olduğu gözlemlenmiştir. $\mathrm{Bu}$ bulgular, bellek organizasyonunun ve bireysel bellek stratejilerinin bozulmaya daha yatkın olduğu durumlarda ortaklaşa ketleme olasılığının arttığını göstermekte ve bellek organizasyonu açıklamasını desteklemektedir.

Grup çalışması sonrası gerçekleştirilen bireysel hatırlama testlerinde, katılımcıların hatırladıkları bilgilerin dahil oldukları gruptaki diğer grup üyelerinin hatırladıklarıyla dikkat çekici bir örtüşme gösterdiği de gözlemlenmektedir (Blumen ve Rajaram, 2008). $\mathrm{Bu}$ örtüşmenin ortaklaşa hatırlama ve ketlemenin bir sonucu olduğu düşünülür (Blumen ve Rajaram, 2008; Pereira-Pasarin ve Rajaram, 2011). Bu da ortaklaşa hatırlama ve ketlemenin bireylerin geçmişe ilişkin ortak bir bellek oluşturma sürecine yön veren mekanizmalardan biri olabileceğine işaret eder (Rajaram ve Pereira-Pasarin, 2010).

Sosyal Paylaşımlı Hatırlama Yoluyla Unutma. Sosyal ortamda bilgi aktarımı yoluyla bellekte temsil edilen ve hatırlanan bilgilerin grup tarafından nasıl şekillendirildiğini gösteren bir başka deneysel paradigma sosyal paylaşımlı hatırlamaya bağlı unutma- 
dır (socially-shared retrieval induced forgetting/SS-RIF). Bu yöntem, hatırlamaya bağlı unutma (retrieval-induced forgetting/RIF; Anderson, Bjork ve Bjork, 1994) paradigmasından esinlenilerek tasarlanmıştır. Orijinal paradigmada, katılımcılar meyve-çilek, meyve-kiraz, sebze-brokoli, sebze-lahana gibi kategori-hedef kelime çiftlerini öğrenirler. Ardından kelime kökü tamamlama görevi ile hatırlama pratiği yaparlar (örn., meyve-çi____ Hatırlama pratiği, bazı kategorilerdeki kelimelerin bir kısmıyla (örn., meyve-çilek) seçici olarak yapılır; diğer çiftlerle (örn., meyve-kiraz, sebze-brokoli, sebze-lahana) pratik yapılmaz. Son aşamada, katılımcılardan serbest hatırlama yoluyla olabildiğince çok sayıda kelimeyi hatırlamaları istenir. Bu paradigmanın kullanıldığ deneylerde tipik olarak iki bulgu elde edilir. Bunlardan ilki pratik etkidir. Pratik etkiye göre, öğrenme aşamasından sonra seçici hatıllama pratiğine maruz kalan uyaranlar (örn., meyve-çilek) diğer tüm uyaranlardan daha iyi hatırlanır. Bu durum, hatırlama pratiğine maruz kalan uyaranların bellekte güçlenerek kolaylıkla erişilebilir hale gelmeleri ve daha iyi hatırlanmalarıyla açıklanır. İkinci bulgu hatırlamaya bağlı unutmadır. Hatırlama pratiğine maruz kalan uyaranlarla ilişkili fakat hatırlama pratiğine hiç maruz kalmayan uyaranlar (örn., meyve-kiraz), hatırlama pratiğine hiç maruz kalmamış kategorilerdeki uyaranlar da dahil olmak üzere (örn., sebze-brokoli, sebze-lahana) diğer tüm uyaranlardan daha az hatırlanır. Bir başka deyişle, en düşük bellek performansı, hatırlama pratiğine dahil olan kategorideki hatırlanmayan uyaranlar (örn., kiraz) için gösterilir. $\mathrm{Bu}$ durum için yaygın olarak kabul edilen açıklama ketleme açılamasıdır (Anderson ve ark., 1994; Anderson, Bjork ve Bjork, 2000). Buna göre, insanlar belirli bir bilgiyi hatırlamaya çalışırken bu bilgiyle ilişkili diğer bilgiler (örn., aynı kategorideki diğer kelimeler) etkin hale gelmek için yarışırlar. İstenen bilgiye erişip hatırlayabilmek için etkin hale gelmeye çalışan ilişkili diğer bilgilerin ketlenmesi gerekir. Özetle, hatırlamaya bağ11 unutma paradigması, hatırlama pratiğine maruz kalan uyaranların bellekte güçlenerek kolaylıkla erişilebilir hale geldiğini ve daha iyi hatırlandığını, bu uyaranlarla ilişkili ama hatırlama pratiğine maruz kalmamış diğer uyaranların ise ketlenerek unutulduğunu gösterir.

Cuc, Ozuru, Manier ve Hirst (2006), bir konu üzerine konuşulurken konuyla ilgili bazı bilgilere değinildiğini, bazılarına ise değinilmediğini ve bu durumun konuşmanın tarafları için sosyal paylaşımlı hatırlamaya bağlı unutma ile sonuçlanabileceğini düşünmüşlerdir. Bu düşünceden yola çıkarak, hatırlamaya bağlı unutma paradigmasına sosyal bir boyut eklemişler, paradigmayı anlatıcı(lar) ve dinleyici(ler) içerecek şekilde yeniden 
tasarlamışlardır. Böylece anlatıcının başta çalışılan bir dizi bilgi arasından seçici biçimde bazı bilgileri hatırlayıp, diğer bilgilerden hiç söz etmemeye yönlendirilmesi halinde, söz edilmeyen bilgilerin hem anlatıcı hem de dinleyici tarafından unutulduğunu göstermişlerdir. Sosyal paylaşımlı hatırlamaya bağlı unutma etkisi, çeşitli büyüklükteki gruplarda hatırlama pratiklerinin farklı sıklıktaki tekrarlarıyla (Coman, Kolling, Lewis ve Hirst, 2012; Coman, Momennejad, Drach ve Geana, 2016), hikayeler ve kelime listeleri gibi basit uyaranlar (Cuc ve ark., 2006; 2007) ya da kürtaj ve ötanazi gibi tartışmalı konularla (Coman ve Hirst, 2012) test edildiğinde de tutarlı bir biçimde gözlemlenmektedir.

Belleğin grup düzeyinde hatırlama/unutma yoluyla şekillenmesinde, etkileşime giren tarafların sosyal kimliğinin de önemli bir rolü olduğu düşünülmektedir. Örneğin, anlatıcı ile dinleyicinin ortak bir sosyal kimliğe sahip olduğu koşulda (örn., her ikisi de Princeton Üniversitesi öğrencisi ise) sosyal paylaşımlı hatırlamaya bağlı unutma gözlemlenirken, anlatıcı ve dinleyicinin ortak bir sosyal kimliği paylaşmadığı koşulda (örn., anlatıcı Yale Üniversitesi, dinleyici Princeton Üniversitesi öğrencisi ise) sosyal paylaşımlı hatırlamaya bağlı unutma gözlemlenmemiştir (Coman ve Hirst, 2015). Benzer şekilde, bir gruba hitap eden tek bir konuşmacının grupla aynı sosyal kimliği paylaştığ durumda (örn., New Yorklu bir gruba konuşan New Yorklu konuşmac1) grup üyelerinde hatırlamaya bağlı unutma gözlemlenirken, konuşmacının grupla aynı sosyal kimliği paylaşmadığı durumda (örn., New Yorklu bir gruba konuşan Utahlı bir konuşmacı) bu etkinin gözlemlenmemesi de belleğin grup düzeyinde hatırlama/unutma yoluyla şekillenmesinde sosyal kimliğin rolünü destekler niteliktedir (Yamashiro, 2017).

\section{Deneysel Paradigmaların Toplumsal Bellek Araştırmalarına Katkısı}

Önceki bölümlerde özetlendiği gibi, bireyler hatırlar ama bunu kendi deneyimlerinin ötesinde başka kaynaklardan gelen bilgileri de (bu bilgiler yanlış bile olsa) benimseyerek, toplumsal ve kültürel bir yapı içinde belleği yeniden yapılandırarak gerçekleştirirler. Belleğin sosyal bulaşıcılığg, ortaklaşa ya da seçici hatırlama ve unutma, sadece bireylerin belleğini yeniden şekillendirmekle kalmayıp, farklı bireysel bellek temsillerinin birbirine yakınsayarak ortak bir bellek temsiline dönüşmesini de yönlendirebilir. Bu anlamda, yukarıda değindiğimiz deneysel paradigmalar, bir topluluğun ortak belleğinin oluşma sürecinin altında yatan bilişsel mekanizmaların temsilleri olarak düşünülebilmektedir (Hirst ve Coman, 2018; Hirst ve Echterhoff, 2012; Pereira-Pasarin ve Rajaram, 2011; Roediger ve ark., 2009). Laboratuvar ortamında kelime listeleri ya da k1sa 
hikayeler gibi basit uyaranlarla gerçekleştirilen çalışmalar, toplumsal olayların nasıll hatırlandığını doğrudan inceleyen başka deneysel çalışmalara yön vermeleri ve betimleyici çalışmaların anlamlandırılmasına katkı sunmaları bakımından önemlidir. Derlemenin bu bölümünde, yukarıda değinilen deneysel çalışmalarla toplumsal bellekteki olayların hatırlanmasına ilişkin bulgular arasındaki bağlantıların ortaya konması hedeflenmektedir.

Toplumsal Belleğin Sosyal Bağlamda Yapılandırılması. Toplumsal belleğin sosyal bağlamda başkalarının bellek ve anlatılarıyla beslenerek yeniden yapılandırılan bir bellek türü olmasına ilişkin çalışmalar gitgide artmaktadır (Stone ve Jay, 2019). Bu çalı̧̧malar, genellikle medya ve benzeri harici kaynaklarda paylaşılan bilgilerin insanların bir toplumsal olay hakkında hatırladıkları bilgileri miktar ve içerik yönünden nasıl şekillendirdiğini ele almaktadır. Aktarım ve etkileşim odaklı bu araştırmaları özetlemeden önce, insanların toplumsal olaylar hakkında hatırladıkları bilgilerin doğruluğunu inceleyen çalışmalara değinmek toplumsal olaylara ilişkin belleğin zaman içinde değişime ve bozulmaya açık olduğunu ortaya koymak bakımından faydalı olacaktır. Bu konuya ilişkin bazı çalışmalarda, katılımcılara bir toplumsal olayla ilgili aslında hiçbir zaman yayınlanmamış bir video kaydını izleyip izlemedikleri sorulmuştur. Sonuç olarak, katılımcıların \%73'ü 2001'deki 11 Eylül saldırılarında Dünya Ticaret Merkezi'ne çarpan ilk uçağın (Pezdek, 2003), \%66'sı 1992'deki Amsterdam uçak kazasının (Crombag, Wagenaar ve Van Koppen, 1996) ve \%45'i 1997'de Prenses Diana'nın hayatını kaybettiği Paris’teki araba kazasının (Ost, Vrij, Costall ve Bull, 2002) aslında hiçbir zaman yayınlanmamış görüntülerini izlediklerini belirtmişlerdir. Bazı çalışmalarda ise duygusal uyarımın yüksek olduğu bir olayın öğrenildiği ana ilişkin otobiyografik anılar olarak tanımlanan flaş anıların (Brown ve Kulik, 1977) ve olayın kendisine ilişkin hatırlanan bilgilerin zaman içindeki değişimi karşılaştırmalı olarak ele alınmıştır (örn., Hirst ve ark., 2009; Pezdek, 2003; Tekcan, Ece, Gülgöz ve Er, 2003). Örneğin, Tekcan ve meslektaşları (2003) 11 Eylül saldırılarından üç gün, altı hafta ve bir yıl sonra hem flaş anıların hem de olay hakkında hatırlanan bilgilerin ${ }^{4}$ tutarlılığını incelemişlerdir. Zaman içinde otobiyografik anıların (örn., katılımcıların olay anında nerede oldukları bilgisi-

4 Çalışmada ele alınan olay bir toplumsal olay olmakla beraber, olay belleği (event memory) ve toplumsal belleğin birebir aynı anlama geldiği düşünülmemelidir. Olay belleği, bireylerin deneyimledikleri bir olaya iliş̧kin hatırladıkları detayları (örn., 11 Eylül saldırılarında kaçırılan uçak sayısı) içermektedir (Tekcan ve ark., 2003). Toplumsal bellek ise toplumdaki kültürel ürünlerle ve grup kimliğiyle etkileşime giren, bireyler arasında aktarılan ve topluluk içinde dağılıp yayılan bireysel anıların ve bilgilerin paylaşılan bir özeti olarak tanımlanmaktadır (Hirst ve Manier, 2008). 
nin) tutarlılık düzeyinde kayda değer bir değişiklik gözlemlenmezken, olay hakkında hatırlanan bilgilerin (örn., kaçırılan uçak sayısının) tutarlılık düzeyinin azaldığını ortaya koymuşlardır. Bu bulgular, toplumsal olaylara ilişkin belleğin zayıflayıp bozulmaya yatkin olduğunu göstermektedir.

İnsanların toplumsal olayları ne şekilde hatırladıkları, sosyal etkileşimin bir parçası olarak ele alınabilecek kitle iletişim araçlarında olayların nasıl aktarıldığının da bir yansımasıdır (Hirst ve ark., 2009; Lewandowsky, Ecker, Seifert, Schwarz ve Cook, 2012; Lewandowsky, Stritzke, Freund, Oberauer ve Krueger, 2013; Marsh ve Rajaram, 2019; Páez ve ark., 2009; Wang, 2019; Wang ve Aydın, 2009). Örneğin, Hirst ve meslektaşları (2009), 11 Eylül saldırıları hakkında hatırlanan bilgilerin doğruluk düzeyinin olaydan sonraki birinci haftadan başlayarak bir düşüş gösterdiğini ve 11. ayda doğruluk düzeyindeki bu düşüşün daha da belirgin hale geldiğini ortaya koydular. Katılımc1lar 11 Eylül saldırılarından bir hafta sonra olayla ilgili soruların \%88'ine, 11 ay sonra ise \%77'sine doğru yanıt verebildiler. Olaydan sonraki 11. aydan 35. aya kadar geçen sürede ise hatırlanan bilgilerin doğruluk düzeylerinde bir düşüş gözlemlenmedi. Ancak bu hatırlama örüntüsü, bir başka araştırmada ortaya konan Challenger patlamasına ilişkin hatırlama örüntüsüyle karşılaştırıldığında bulguların birbiriyle örtüşmediği görüldü. Challenger patlaması hakkında hatırlanan bilgilerin doğruluk düzeyi 36 ay boyunca tekrarlanan ölçümlerde süreklilik arz eden bir düşüş göstermişti (Bohannon ve Symons, 1992). Hirst ve meslektaşları (2009), 11 Eylül saldırıları ve Challenger patlamasının hatırlanma örüntülerindeki bu farklılaşmanın gerek kişiler arası iletişim gerekse medya aracılıyla bu iki olay üzerine yapılan hatırlama pratiğiyle ilgili olabileceğini düşündüler. Böylece, bu toplumsal olayların hatırlanma (unutulma) eğrileriyle olayların basında yer alma sıklığının zaman içindeki değişimini karşılaştırdılar. Challenger patlamasının hatırlanma eğrisi, olayın basında yer alma sıklığıyla birlikte süreklilik arz eden bir düşüş göstermekteydi. 11 Eylül saldırılarının hatırlanma eğrisi ve olayın basında yer alma sıklığı ise olaydan sonraki birinci haftadan 11. aya kadar birlikte düşüş gösterirken, olaydan sonraki 11. aydan 35. aya kadar birlikte yatay bir seyir izlemekteydi. Bir başka deyişle, olayların basında yer alma sıklığında zaman içinde görülen değişimin olayların hatırlanma düzeyindeki değişimi kestirdiğini buldular. Aynı araştırmadaki bir diğer dikkat çekici bulgu, 11 Eylül saldırıları sırasında Amerika Birleşik Devletleri (ABD) başkanı olan George W. Bush'un olay anında nerede olduğuyla ilgili sorulara verilen cevaplarda ortaya çıktı. Michael Moore'un Fahrenheit 9/11 adlı belgeseline göre (2004), Bush olay 
anında (saldırı haberi kendisine ulaşmış olmasına rağmen) bir anaokulundaki öğrencilere Benim Evcil Keçim (My Pet Goat) adlı kitabı okumaktaydı. Hirst ve meslektaşları, bu belgeseli izleyen katılımcıların 'Bush'un olay anında nerede olduğu' sorusuna verdikleri yanıtları ayrıca incelediler ve Michael Moore etkisi adını verdikleri bir bulguya ulaştılar. Buna göre, Fahrenheit 9/11 belgeseli yayımlanmadan önce (olayın 11. ayında) bu katılımcıların sadece \%60’1 soruya doğru yanıt verirken, belgesel yayımlandıktan sonra (olayın 35. ayında) katılımcıların \%91'i bu soruya doğru yanıt verdiler. Hirst ve arkadaşları (2009) bu bulguları, bireylerin topluluktaki diğer bireyler ve/veya medya ile girdikleri iletişim ve etkileşim sonucunda toplumsal olaylar üzerine hatırlama pratiği yapmaları ve olaylar hakkında hatırladıklarını yeniden yapılandırmalarıyla ilişkilendirmektedir.

Toplumsal olayların nasıl hatırlandığı, olayların internet ve sosyal medyada (Facebook ve Twitter gibi platformlarda) nasıl ele alındığının da bir yansıması olabilir. Görece yakın tarihli çalışmalar, bireylerin bilgileri hatırlamak için biyolojik belleğin yanı sıra internet ve sosyal medya gibi dışsal bilgi depolama sistemlerini de kullandıklarını göstermektedir (örn., Henkel, 2014; Sparrow, Liu ve Wegner, 2011). Belleğin internet ve sosyal medya üzerinden sürdürülen bir sosyal etkileşim yoluyla yapılandırılmasına yönelik çalışmalar henüz sınırlı sayıdadır (Stone ve Wang, 2019). Ancak elde edilen bulgular, sosyal medya ortamında karşılaşılan yanıltıcı bir bilginin, bireyin halihazırdaki inançları ve grup kimliğiyle örtüşmesi (Yardi ve Boyd, 2010), kalabalık bir grup tarafından olumlu karşılık bulması (örn., beğenme/like veya paylaşma/retweet; Li ve Sakamoto, 2014) veya kaynağının güvenilir kabul edilmesi (Fenn, Griffin, Uitvlugt ve Ravizza, 2014) gibi durumlarda bireyi bellek yanılsamasına yönlendirebileceğini ortaya koymaktadır. İlerleyen dönemlerde, sosyal medya aracılığıyla ortaklaşa hatırlama ve unutmanın toplumsal belleğin şekillenmesi üzerindeki rolünü doğrudan incelemeyi amaçlayan çalışmalar yapılması bu konuda daha kapsamlı bilgi edinmemizi sağlayacaktir.

Bir toplumsal olay hakkında hatırlananların yeniden yapılandırılmasında ortaklaşa hatırlama ve sosyal paylaşımlı hatırlamaya bağlı unutmanın rolünü doğrudan inceleyen deneysel çalışmalar da bulunmaktadır. Örneğin, Yaron-Antar ve Nachson (2006), İsrailli katılımcılardan Itzhak Rabin suikastını ortaklaşa hatırlama paradigması içinde hatırlamalarını istemişlerdir. Katılımcılar, olaya ilişkin bilgileri üçerli gruplar halinde ya da bireysel çalışarak hatırlamışlardır. Ayrıca gruplardaki kişi sayısı kadar bireysel çalışan 
katılımcı tarafından hatırlanan bilgilerin, örtüşen bilgi olmayacak şekilde, bir karması oluşturulmuş böylece nominal hatırlama miktarı hesaplanmıştır. "Suikast ne zaman oldu?", "Başbakan kaç kurşunla vuruldu?" gibi sorulara verilen yanıtlara göre, bireysel çalışan katılımcılara kıyasla, grup halinde çalışan katılımcıların hatırladıkları bilgi miktarının daha fazla olduğu bulunmuştur. Bu bulgu, ortaklaşa kolaylaştırma etkisini göstermektedir. Öte yandan grup halinde çalışan katılımcıların hatırladıkları bilgi miktarına kıyasla, nominal hatırlama miktarının daha fazla olduğu bulunmuştur. Bu bulgu ise ortaklaşa ketleme etkisini göstermektedir. Bir başka deyişle, standart ortaklaşa kolaylaştırma ve ortaklaşa ketleme etkileri sadece basit uyaranlar için değil, toplumsal olaylar için de gözlemlenmektedir (Yaron-Antar ve Nachson, 2006).

Önceki bölümlerde, sosyal paylaşımlı hatırlamaya bağlı unutma paradigmasının kullanıldığı deneylerde anlatıcı ile dinleyicinin farklı sosyal kimliklere sahip olduğu durumda seçici hatırlamaya bağlı unutmanın ortaya çıkma olasılığının daha düşük olduğu çalışmalara değinilmişti (örn., Coman ve Hirst, 2015). Bu çalışmalarla tutarlı biçimde, bir toplumsal olay hakkında paylaşılan bilginin sosyal kimliği tehdit ettiği durumlarda da hatırlamaya bağlı unutmanın görülmeyebileceği ortaya konmuştur. Örneğin, Castano ve Giner-Sorolla (2006), olumsuz bir olayın başrolündeki kişiyle aynı gruba dahil olan insanların, grubun olaydaki sorumluluğunu azaltmaya yönelik gerekçeleri hatırlamaya güdülendiklerini ileri sürmüşlerdir. Coman ve arkadaşları (2014), bu görüşü sınamak için Irak Savaşı'nda Afganistanlı ya da Amerikalı askerlerin başrolde olduğu bazı vahşet olayları hakkındaki metinleri ve bu olaylarla ilgili gerekçeleri Amerikalı katılımcılara okuttular. Seçici hatırlama pratiği aşamasında, katılımcılar verilen olaylardan rastgele ikisini hatırlaması istenen birinin video kaydını izlediler. Videodaki kişi olaylara ilişkin detaylardan söz etti, fakat olayların gerekçelerinden hiç söz etmedi. Sonuç olarak, hikayelerdeki askerlerin Afganistanlı olduğu durumda hatırlamaya bağlı unutma gözlemlendi. Amerikalı katılımcılar Afganistanlı askerlerin başrolde olduğu olumsuz olayların gerekçelerini hatırlamadılar. Ancak askerlerin Amerika uyruklu olduğu durumda hatırlamaya bağlı unutma görülmedi ve katılımcılar bu kez olayların gerekçelerini de hatırladılar. Bu bulgular, insanların kendileri için kişisel anlamı olan bir olayı hatırlarken grup kimliğini ve benlik algısını destekleyen detayları seçici olarak hatırladıkları görüşüyle uyumludur (örn., Alea ve Bluck, 2003; Páez ve ark., 2009; Páez ve Liu, 2010). Özetle, belleğin sosyal bağlamdaki hatırlama pratiklerinden ne ölçüde etkileneceği, bir olay hakkında hangi detayların hatırlanıp hangi detayların hatırlanmayacağı 
grup kimliği ve benlik algısına bağlı olabilir. İnsanların grup kimliği ve benlik algısı üzerinde bir tehdit algıladıklarında bu tehdidi ortadan kaldıracak bilgileri hatırlama eğiliminde olmaları dikkat çekicidir.

Bir olayın diğer kaynaklardan alınan bilgilerle yapılandırılarak hatırlanması, olayın bellekteki temsiliyle birlikte olaya ilişkin tutum ve inançları şekillendirme potansiyeline de sahiptir (Echterhoff, Higgins ve Levine, 2009). Örneğin Harris, Barnier, Sutton ve Keil (2010), katılımcıların Avustralyalı vahşi yaşam belgeselcisi Steve Irwin'in belgesel çekimi sırasında bir vatoz balığı tarafindan zehirlenerek öldürülmesi olayını duydukları ana ilişkin flaş anılarını ve olay hakkındaki tutumlarını ortaklaşa hatırlama paradigması içinde incelediler. Bu çalışmada, ortaklaşa hatırlama grubundaki katılımcıların hem olaya ilişkin hatırladıkları flaş anıların hem de olaya karşı tutumlarının grup tartışmaları yönünde yeniden şekillendiği ve birbirine yakınsadığ üç aşamasını da bireysel olarak tamamlayan katılımcıların Steve Irwin'in ölüm haberiyle yaşadıkları şok, üzüntü ve Irwin'in ölümünün Avustralya için ne denli büyük bir kayıp olduğuna ilişkin değerlendirmeleri ilk aşamadan son aşamaya kadar bir değişim göstermezken, grup sürecine dahil olan katılımcıların değerlendirmeleri ilk aşamaya k1yasla sonraki aşamalarda bir ile 10 arasında puanlanan ölçeğin orta noktalarına doğru kayma gösterdi. Bireyler grup tartışmaları sırasında olay hakkındaki bireysel değerlendirmelerini yeniden yapılandırarak bir orta noktada birbirlerine yakınsama eğilimi gösterdiler. Bu bulgular, insanların bir olaya ilişkin tutumlarını sosyal etkileşim yoluyla yeniden yapılandırabileceklerine ve grup içinde ortak tutum geliştirebileceklerine işaret etmektedir (Harris ve ark., 2010).

Özetle, toplumsal olaylara ilişkin belleğin nasıl yapılandırıldığını doğrudan inceleyen çalışmalarla laboratuvar ortamında basit uyaranlar kullanılarak gerçekleştirilen deneysel çalışmalar birbiriyle örtüşen bulgular ortaya koymaktadır. Bu da bilişsel psikolojinin kavram ve yöntemlerinin, toplumsal belleğin oluşumu ve şekillenmesinin altında yatan mekanizmaları anlamak için araştırmacılara elverişli bir yol sunabileceğini göstermektedir.

\section{Toplumsal Olayların Hatırlanma Örüntüleri}

Toplumsal olayların hatırlanma örüntülerine odaklanan araştırmalarda, katılımcılardan belirli bir dönemde (örn., son 70 yılda) hatırladıkları en önemli toplumsal olayın ne olduğunu belirtmeleri ve yaş, eğitim gibi demografik bilgiler ile olaya ilişkin değerlen- 
dirmelerini içeren (örn., olayın duygusal değerliği) bazı anket sorularını yanıtlamaları istenmektedir. Bu betimleyici çalışmalar, insanların en sık hatırladıkları toplumsal olayların bir dökümünü sunarak bir toplumun belleğinde hangi olayların yer aldığını ortaya koyar. Bunu yaparken, farklı zamanlarda ya da farklı ülkelerden elde edilen verileri karşılaştırarak toplumun belleğinin zaman içinde ya da bir topluluktan diğerine nasıl değiştiğini ve bu değişimlerin olası nedenlerini de inceler (örn., Corning, Gaidys ve Schuman, 2013; Schuman, Akiyama ve Knauper, 1998; Schuman ve Rodgers, 2004; Schuman ve Scott, 1989; Tekcan, Boduroglu, Mutlutürk ve Erciyes, 2017; Wertsch, 2002). Öte yandan, bu çalışmalar, sosyal etkileşimin toplumsal belleği nasıl şekillendirdiğini incelemeyi amaçlamamaktadır. Yine de farklı araştırma eksenleri arasındaki bağlantılar, gelecekteki araştırmalara ilham verebilecek potansiyele sahip olabilir. Dolayısıyla bu bölümde, betimleyici çalışmaların ortaya koyduğu hatırlama örüntüleri ile sosyal etkileşimin bellek üzerindeki rolünü inceleyen deneysel çalışmaların sonuçları arasındaki bağlantılar incelenecektir.

Gerek kişiler arası iletişim gerekse tarih kitapları, anmalar, kutlamalar veya ulusal bayramlar gibi kültürel ürünler, toplumsal geçmişe ilişkin bazı bilgilere dikkat çekerek bu bilgileri tekrar tekrar hatırlatırlar (Blatz ve Ross, 2009; Páez ve ark., 2009; Roediger ve ark., 2009; Wertsch, 2002; Wertsch ve Roediger, 2008). Örneğin, Amerikalı öğrencilerin tarih kitaplarında Almanya'nın Sovyet Sosyalist Cumhuriyetler Birliği'ne (SSCB) saldırması yerine Pearl Harbor Saldırısı'na geniş yer verilmesi ve sınavlarda tekrar tekrar bununla ilgili sorular sorulmasının etkisiyle, bir Amerikalı öğrenci örnekleminde bu konudaki bilgilerin bellekten geri getirilmesi daha olasıdır (Roediger ve ark., 2009; Stone ve Jay, 2019). Wertsch’ün (2002) Amerikalı ve Rus öğrencilerle gerçekleştirdiği ve II. Dünya Savaşı hakkında hatırladıkları en önemli olayları listelemelerini istediği çalışmada elde ettiği hatırlama örüntüleri de bu görüşü destekler niteliktedir. Bu çalışmada, Amerikalı öğrencilerin II. Dünya Savaşı'nın en önemli olayları listesindeki ilk üç olay Pearl Harbor Saldırısı, Midway Muharebesi ve Normandiya Muharebesi iken Rus öğrencilerin listesindeki ilk üç olay Almanya'nın SSCB'ye saldırması, Moskova Muharebesi ve Stalingrad Muharebesi olmuştur. İki grubun listelerinde yer alan ilk altı olay arasında hiçbir örtüşme görülmemiştir. Benzer şekilde, çeşitli ülkelerdeki katılımcılara son elli yılda dünyada en önemli gördükleri toplumsal olayın ne olduğu sorulduğunda, Amerika ve Japonya'da en sık belirtilen olay II. Dünya Savaşı (Schuman ve ark., 1998; Schuman ve Rodgers, 2004) iken Almanya'da en sık belirtilen olay Almanya’nın Birleş- 
mesi (Schuman ve ark., 1998) olmuştur. Corning ve arkadaşları (2013) ise Litvanya'da yaşayan Litvanya ve Rusya kökenli bireylerin hatırladıkları en önemli toplumsal olaylar bazında bu iki grubun toplumsal belleğinde hangi olayların daha erişilebilir olduğunu 1989, 1993 ve 2009'da topladıkları verilerle karşılaştırmalı olarak incelemişlerdir. Litvanya kökenli bireylerin en sık hatırladıkları olaylar Litvanya'nın Yeniden Doğuşu (1989: \%49.7) ve Litvanya’nın Bağımsızlığ1 (1993: \%38.3; 2009: \%58.2) iken Rusya kökenli bireylerin en sık hatırladıkları olayların Perestroika (1989: \%43.1), II. Dünya Savaş1 (1993: \%35.8) ve Litvanya'nın Bağımsızlı̆̆1 (2009: \%45.2) olduğu bulunmuştur. Corning ve arkadaşlarının bu çalışması, aynı ülkede yaşayan farklı etnik gruplara mensup bireylerin toplumsal bellek örüntülerinin son derece farklı olabileceğini ortaya koyması bakımından dikkate değerdir. Hatırlama örüntülerindeki bu tür farklılıkların, bireylerin belirtilen diğer olaylardan haberdar olmaması nedeniyle değil, bu olayların üyesi oldukları grubun "şematik anlatı kalıplarında" daha az yer alması, günlük yaşamda bu olaylara daha az değinilmesi ve dolayısıyla bu olayların bellekte kolayca erişilebilir olmaması nedeniyle ortaya çıktığı düşünülmektedir (Wertsch, 2002, s. 57; Wertsch ve Roediger, 2008).

Bir toplumdaki önemli olayların nasıl hatırlandığı içerik bazında incelendiğinde, kültürel ürünlerin bu süreçteki etkisinin olayın bizzat deneyimlenmiş olup olmamasına göre değişebildiği görülmektedir (Muller, Bermejo ve Hirst, 2016; 2018). Toplumsal olaylar, tarih kitapları ve anmalar gibi kültürel ürünlerde genellikle tarihsel, sosyal ve politik bağlam içinde ele alınırlar (Muller ve ark., 2016; 2018; Stone ve Jay, 2019). Dolayısıyla bir olayı deneyimlememiş genç bireylerin olaya ilişkin anlatıları kültürel ürünlerde sunulan tarihsel, sosyal ve politik bağlamı yansıtırken, aynı olayı bizzat deneyimlemiş ileri yaştaki bireylerin anlatıları daha çok kişisel anılara ya da başkalarının (örn., aile bireyleri ve arkadaşlar) kişisel anılarına dayanmaktadır (Muller ve ark., 2018). Öte yandan, insanların bir toplumsal olaya ilişkin anlatılarının kültürel ürünlerdeki anlatıları ne kadar yansıttığı ile olayın bizzat deneyimlenmiş olup olmaması arasındaki ilişki uzak geçmişteki olaylar (örn., 1976 Arjantin darbesi) için gözlemlenirken, görece yakın geçmişteki olaylar (örn., 2001 Ekonomik krizi) için gözlemlenmemektedir (Muller ve ark., 2018). Bu durumun yakın geçmişteki olayların henüz kültürel ürünlerde yeterince yer bulmaması ve olay hakkındaki bilgilerin daha çok kişisel iletişim yoluyla edinilmesi ile ilişkili olduğu düşünülmektedir (Muller ve ark., 2016; 2018). Bir başka deyişle, toplumsal olayların sosyal etkileşim yoluyla ne ölçüde şekilleneceği ya da etkileşimin kaynağ1- 
nın ne olacağı (örn., kişisel anılar, başkalarının anıları ve/veya kültürel ürünler) olayın bizzat deneyimlenip deneyimlenmediğiyle ve olayın ne kadar yakın geçmişte gerçekleştiğiyle ilişkili olabilir (Muller ve ark., 2016; 2018).

Toplumsal olayların hatırlanma örüntülerini inceleyen çalışmalar, gruplar arası farklılıkların ötesinde grup içi benzerlikleri sergilemeleri bakımından da önemlidir. Aslında bu çalışmaların temel amaçlarından biri, bir toplumun ortak belleğini hangi olayların oluşturduğunu keşfetmektir. Bu açıdan bakıldığında dikkat çekici noktalardan biri, hemen her toplumun son 50-70 yıllık tarihinde deneyimlediği sayısız önemli olay olmasına rağmen, bir toplumu oluşturan bireylerin hatırladıkları en önemli olaylar konusunda belli başlı 10-15 olay üzerinde bir konsensüs oluşmuş olmasıdır. Örneğin, Schuman ve Rodgers'ın (2004) 1985 ve 2000'de ABD'de topladıkları ve karşılaştırmalı olarak inceledikleri verilerde katılımcıların en az yarısı (1985: \%58.8; 2000: \%50) II. Dünya Savaş1, Vietnam Savaşı, Büyük Buhran ve Kennedy suikastı gibi belli başlı olayları son 50 yılın en önemli olayları olarak belirtmekte ve 11 olaydan oluşan bir önemli olaylar listesi üzerinde konsensüse varmaktadır. ${ }^{5}$ Türkiye'nin toplumsal belleğinde yer alan en önemli olayların hatırlanma örüntülerini inceleyen ve 2013 yılında Türkiye temsili bir örneklemle gerçekleştirilen araştırmanın bulgularına göre, 12 Eylül Askeri Darbesi (\%25.3) ve 1999 Marmara Depremi (\%18.1) Türkiye'de en s1k hatırlanan ilk iki olay olarak öne çıkarken, toplamda katılımcıların \%71.2'si 10 olaydan oluşan bir önemli olaylar listesi üzerinde konsensüs oluşturmaktadır (Olay listesinin tamamı için bkz. Tekcan ve ark., 2017). Başta da belirtildiği gibi toplumsal bellekteki olayların hatırlanma örüntülerine ilişkin çalışmaların sosyal etkileşimin toplumsal belleğin yapılandırılmasındaki rolünü incelemek gibi bir amacı yoktur ve bu konuya yönelik çalışmalarla hatırlama örüntüleri arasında kurulan bağlantılar spekülatif düzeydedir. Öte yandan, bir toplumdaki bireylerin belleğinde çok sayıda olay arasında neden bazı olayların daha erişilebilir, bazılarının ise (olay anında yarattıkları etki şiddeti benzer olsa bile) daha az erişilebilir olduğu sorusu önceki bölümlerde özetlenen deneysel bulguların 1şı̆̆ında değerlendirilmeye açıktır.

5 Schuman ve Rodgers'ın (2004) 11 Eylül saldırılarından kısa bir süre sonra, 2002 yılında topladıkları verilerde katılımcıların \%31.2'si 11 Eylül saldırılarını, \%41.2'si ise listedeki diğer 11 olayı son 50 yıldaki en önemli tarihsel olay olarak belirtmişlerdir. Böylece katılımcıların toplamda \%72.4'ü 12 olay üzerinde bir konsensüse varmış görünmektedir. Ancak verilerin 11 Eylül saldırılarından çok kısa bir süre sonra toplanması ve veri toplama sürecinde 11 Eylül saldırılarının henüz belleğin pekiştirme (consolidation) süreçlerinden geçmemiş olma olasılı̆̆ı nedeniyle bu veri seti diğer iki veri setinden ayrı tutulmuştur. 
Özetle, toplumsal olayların hatırlanma örüntülerini inceleyen çalışmalar toplumsal belleğin sosyal bağlamda yapılandırılmasına ilişkin süreçleri doğrudan inceleme amacı gütmeseler de, hatırlanma örüntülerinin ortaya koydukları benzerlikler ve farklılıklar, deneysel bulgularla tutarlılık göstermektedir. Belirli bir grupta, o grup için önemli olan, üzerine sıkça düşünülen ve tartışılan olaylara ilişkin güçlü bir bellek izi oluşabilir ve bu olaylar grubun ortak belleğini oluşturabilir. Bir başka deyişle, en sık hatırlanan toplumsal olaylar, gerçekleştikleri dönemde toplumda yaşayan insanların günlük yaşam örüntüsünü (fabric of daily life; Brown ve ark., 2009; Svob, Brown, Reddon, Uzer ve Lee, 2014) hem fiziksel hem de psikolojik anlamda doğrudan etkilemeleri (Er, 2003), sonrasında ise sosyal bağlamda düzenli olarak anılan ve hatırlanan, zaman içinde bellekte pekiştirilmiş olaylar olmaları nedeniyle toplumun belleğinde güçlü bir yer edinmiş ve kolaylıkla erişilebilir hale gelmiş olabilirler (Mutlutürk ve ark., 2018; Tekcan ve ark., 2017).

\section{TARTIŞMA}

Birey, toplum ve bellek arasındaki çok yönlü bir ilişkiler ağını kapsayan toplumsal bellek kavramı, tarih, sosyoloji, antropoloji ve siyaset bilimi gibi farklı disiplinlerin ilgisini çekmiş, çeşitli kuramsal ve ampirik çalışmalara konu olmuştur. Bellek süreçleri psikoloji disiplininin temel ilgi alanlarından biri olmasına karşın toplumsal bellekle ilgili soruların psikolojinin kavram ve yöntemleriyle ele alınmaya başlanması oldukça yenidir. Yine de günümüzde psikoloji, özellikle de bilişsel psikoloji, hem betimleme hem de çıkarsamaya yönelik araştırma yöntemlerini kullanarak toplumsal bellek literatürüne önemli katkılar sağlamaktadır. Bu derlemede bir özeti sunulan ve toplumsal belleği bilişsel psikoloji bakış açısından ele alan deneysel çalışmalar, toplumsal belleğin oluşumu ve toplumsal olayların hatırlanmasının altında yatan mekanizmaları anlayabilmek için gerçek dünyadaki sosyal ortamların simülasyonlarını yaratmışlardır. Şimdiye kadar elde edilen bulgular, bireysel bilgi ve deneyimlerin başkalarının bellek ve anlatılarıyla beslenerek şekillendirilebildiğine, bazı bireysel bilgi ve deneyimlerin topluluk içinde sıklıkla hatırlanmaları sonucu bellekte güçlendiğine ve daha iyi hatırlandığına, buna bağlı olarak diğer bazı bilgilerin unutulduğuna işaret etmektedir (bkz. Coman ve Hirst, 2012; 2015; Cuc ve ark., 2006; 2007). Böylelikle topluluğu oluşturan farklı bireysel anıların gitgide birbiriyle örtüştüğü ve topluluğun ortak bir geçmiş temsilinin oluştuğu ileri sürülmektedir. Ayrıca sosyal etkileşim sürecinde gerek bilgi kaynağının gerekse bilginin alıcısı olan tarafın önceki bilgileri, zihinsel şemaları, etnik ya da ulusal kimliği, taraflar arasındaki uzmanlık ya da güç ilişkileri gibi sosyokültürel faktörlerin belleğin yeniden 
yapılandırılması ve ortak bir geçmiş temsilinin oluşması sürecini etkilediği ortaya konmaktadır (Bkz. Coman ve ark., 2014; Coman ve Hirst, 2015; Meade ve ark., 2009; Yamashiro, 2017).

Toplumsal olaylara ilişkin betimleyici çalışmalardaki hatırlama örüntüleri ulusal ve etnik kimlik, kuşaklar ya da takip edilen medyaya dayalı gruplar bağlamında incelendiğinde, grup içi benzerlikler ve gruplar arası farklılıklar gözlemlenmektedir (örn., Corning ve ark., 2013; Hirst ve ark., 2009; Schuman ve ark., 1998; Wertsch, 2002). Bu betimleyici bulgular, deneysel bulguların 1şı̆̆ında değerlendirildiğinde, grup kimliği için önemli, sosyal etkileşim ya da kültürel ürünler yoluyla hakkında sıkça düşünülen ve tartışılan, dolayısıyla sıkça hatırlama pratiği yapılarak pekiştirilen toplumsal olayların bellekte güçlü bir yer edindikleri ve kolaylıkla erişilebilir hale geldikleri düşünülebilir (Hirst ve ark., 2009; Mutlutürk ve ark., 2018; Tekcan ve ark., 2017). Bir toplumun anlatı kalıplarında bazı olaylara daha az değinilmesi, günlük yaşamda bu olaylar üzerine daha az düşünülmesi ve tartışılması ise bu olayların toplumun belleğinde daha az erişilebilir olmasıyla sonuçlanabilir (Hirst ve ark., 2009; Wertsch, 2002; Wertsch ve Roediger, 2008).

Toplumsal belleği psikoloji perspektifinden ele alan çalışmalara olan ilgi henüz yakın dönemde yoğunlaşmıştır. Dolayısıyla farklı duygusal değerlikteki (olumlu ve olumsuz) olaylar (Tekcan ve ark., 2017) ya da toplumsal olay sıklı̆̆1 ve sosyal dinamikler bakımından farklılaşan ülkeler (örn., Schuman ve ark., 1998) bazında toplumsal olayların hatırlanma örüntülerine ilişkin bazı bulgular elde edilmiş olsa da bu tür durumlarda sosyal etkileşimin toplumsal bellek üzerinde nasıl bir rolü olduğu belirsizdir. Benzer şekilde, sosyal medya yoluyla etkileşimin toplumsal bellek temsillerini ne yönde etkileyeceği gibi sorular da henüz cevaplanmamıştır. Bu soruların toplumsal bellek süreçlerine ilgi duyan araştırmacıların gündemine girmesi konuya ilişkin literatürün zenginleşmesini sağlayacaktır.

$\mathrm{Bu}$ derlemede, bilişsel psikoloji bakış açısıyla gerçekleştirilen deneysel çalışmalardan elde edilen bulguların toplumsal belleğin altında yatan mekanizmaların anlaşılması bakımından sunduğu katkılara işaret edilmiştir. Bu çalışmaların farklı disiplinlerin yöntem ve bulgularıyla ilişkilendirilerek disiplinler üstü bir anlayışla ele alınması, toplumsal bellek çalışmalarının verimliliğinin artması ve konuyla ilgili yeni araştırma sorularına alan yaratması bakımından önemlidir. 
Hakem Değerlendirmesi: Dış bağımsız.

Çıkar Çatışması: Yazar çıkar çatışması bildirmemiştir.

Finansal Destek: Yazar bu çalışma için finansal destek almadığını beyan etmiştir.

Peer-review: Externally peer-reviewed.

Conflict of Interest: The author has no conflict of interest to declare.

Grant Support: The author declared that this study has received no financial support.

\section{Kaynakça/References}

Alpar, G., Er, N. ve Uçar Boyraz, F. U. (2007). Görgü tanıklığında bellek hataları: Olay sonrası bilginin ve tuzak soruların hatırlama ve kaynak izleme üzerindeki etkisi. Türk Psikoloji Yazıları, 10(20), $1-17$.

Anderson, M. C., Bjork, E. L. ve Bjork, R. A. (2000). Retrieval-induced forgetting: Evidence for a recall-specific mechanism. Psychonomic Bulletin \& Review, 7(3), 522-530. https://doi.org/10.3758/ bf03214366

Anderson, M. C., Bjork, R. A. ve Bjork, E. L. (1994). Remembering can cause forgetting: retrieval dynamics in long-term memory. Journal of Experimental Psychology: Learning, Memory, and Cognition, 20(5), 1063-1087. https://doi.org/10.1037/0278-7393.20.5.1063

Asch, S. E. (1956). Studies of independence and conformity: I. A minority of one against a unanimous majority. Psychological Monographs: General and Applied, 70, 1-70. https://doi.org/10.1037/h0093718

Assmann, J. (1995). Collective memory and cultural identity. New German Critique, 65, 125-133.

Barnier, A. J., Sutton, J., Harris, C. B. ve Wilson, R. A. (2008). A conceptual and empirical framework for the social distribution of cognition: The case of memory. Cognitive Systems Research, 9(1-2), 33-51. https://doi.org/10.1016/j.cogsys.2007.07.002

Bartlett, F. C. (1932/1995). Remembering: A study in experimental and social psychology. Cambridge: Cambridge University Press.

Basden, B. H., Basden, D. R., Bryner, S. ve Thomas III, R. L. (1997). A comparison of group and individual remembering: Does collaboration disrupt retrieval strategies? Journal of Experimental Psychology: Learning, Memory, and Cognition, 23(5), 1176-1189. https://doi.org/10.1037/02787393.23.5.1176

Basden, B. H., Basden, D. R. ve Henry, S. (2000). Costs and benefits of collaborative remembering. Journal of Applied Research in Memory and Cognition, 14(6), 497-507. https://doi. org/10.1002/1099-0720(200011/12)14:6<497::aid-acp665>3.0.co;2-4

Belli, R. F., Lindsay, D. S., Gales, M. S. ve McCarthy, T. T. (1994). Memory impairment and source misattribution in postevent misinformation experiments with short retention intervals. Memory \& Cognition, 22(1), 40-54. https://doi.org/10.3758/bf03202760

Bilgin, N. (2013). Tarih ve kolektif bellek. İstanbul: Bağlam.

Blatz, C. W. ve Ross, M. (2009). Historical memories. P. Boyer ve J. Wertsch (Ed.). Memory in mind and culture içinde (s. 223-237.). New York: Cambridge University Press. https://doi.org/10.1017/ cbo9780511626999.013

Blumen, H. M. ve Rajaram, S. (2008). Influence of re-exposure and retrieval disruption during group collaboration on later individual recall. Memory, 16(3), 231-244. https://doi. org/10.1080/09658210701804495 
Bohannon III, J. N. ve Symons, V. L. (1992). Flashbulb memories: Confidence, consistency, and quantity. E. Winograd ve U. Neisser (Ed.), Emory symposia in cognition, 4. Affect and accuracy in recall: Studies of "flashbulb" memories içinde (s. 65-91). New York, NY, US: Cambridge University Press. https://doi.org/10.1017/cbo9780511664069.005

Brewer, W. F. ve Treyens, J. C. (1981). Role of schemata in memory for places. Cognitive Psychology, 13(2), 207-230. https://doi.org/10.1016/0010-0285(81)90008-6

Brown, R. ve Kulik, J.(1977). Flashbulb memories. Cognition, 5(1), 73-99. https://doi.org/10.1016/00100277(77)90018-x

Brown, N. R., Lee, P. J., Krslak, M., Conrad, F. G., GB Hansen, T., Havelka, J. ve Reddon, J. R. (2009). Living in history: How war, terrorism, and natural disaster affect the organization of autobiographical memory. Psychological Science, 20, 399-405. https://doi.org/10.1037/e527352012-062

Castano, E. ve Giner-Sorolla, R. (2006). Not quite human: Infrahumanization in response to collective responsibility for intergroup killing. Journal of Personality and Social Psychology, 90, 804-818. https://doi.org/10.1037/0022-3514.90.5.804

Chrobak, Q. M. ve Zaragoza, M. S. (2008). Inventing stories: Forcing witnesses to fabricate entire fictitious events leads to freely reported false memories. Psychonomic Bulletin ve Review, 15(6), 1190-1195. https://doi.org/10.3758/pbr.15.6.1190

Coman, A., Brown, A. D., Koppel, J. ve Hirst, W. (2009a). Collective memory from a psychological perspective. International Journal of Politics, Culture, and Society, 22(2), 125-141. https://doi. org/10.1007/s10767-009-9057-9

Coman, A., Manier, D. ve Hirst, W. (2009b) Forgetting the unforgettable through conversation: Socially shared retrieval-induced forgetting of September 11 memories. Psychological Science, 20(5), 627 633. https://doi.org/10.1111/j.1467-9280.2009.02343.x

Coman A ve Hirst W. (2012). Cognition through a social network: The propagation of socially shared retrieval induced forgetting in social networks. Journal of Experimental Psychology: General, 141, 321-336. https://doi.org/10.1037/a0025247

Coman, A. ve Hirst, W. (2015). Social identity and socially shared retrieval-induced forgetting: The effects of group membership. Journal of Experimental Psychology: General, 144, 717-722. https:// doi.org/10.1037/xge0000077

Coman, A., Kolling, A., Lewis, M. ve Hirst, W. (2012). Mnemonic convergence: From empirical data to large-scale dynamics. S.J. Yang, A.M. Greenberg ve M. Endsley (Ed.) International Conference on Social Computing, Behavioral-Cultural Modeling, and Prediction içinde (s. 256-265). Springer, Berlin, Heidelberg. https://doi.org/10.1007/978-3-642-29047-3_31

Coman, A., Momennejad, I., Drach, R. D. ve Geana, A. (2016). Mnemonic convergence in social networks: The emergent properties of cognition at a collective level. Proceedings of the National Academy of Sciences, 113(29), 8171-8176. https://doi.org/10.1073/pnas.1525569113

Coman, A., Stone, C. B., Castano, E. ve Hirst, W. (2014). Justifying atrocities: The effect of moral-disengagement strategies on socially shared retrieval-induced forgetting. Psychological Science, 25(6), 1281-1285. https://doi.org/10.1177/0956797614531024

Congleton, A ve Rajaram S. (2011). The influence of learning methods on collaboration: Prior repeated retrieval enhances retrieval organization, abolishes collaborative inhibition, and promotes postcollaborative memory. Journal of Experimental Psychology: General, 140(4), 535-551. https://doi. org/10.1037/a0024308

Corning, A., Gaidys, V. ve Schuman, H. (2013). Transformative events and generational memory: A case study over time in Lithuania. Sociological Forum, 28(2), 373-394. https://doi.org/10.1111/socf.12023 
Crombag, H. F., Wagenaar, W. A. ve Van Koppen, P. J. (1996). Crashing memories and the problem of 'source monitoring'. Applied Cognitive Psychology, 10(2), 95-104.

Cuc, A., Koppel, J. ve Hirst, W. (2007). Silence is not golden: A case for socially shared retrieval-induced forgetting. Psychological Science, 18(8), 727-737. https://doi.org/10.1111/j.1467-9280.2007.01967.x

Cuc, A., Ozuru, Y., Manier, D. ve Hirst, W. (2006). On the formation of collective memories: The role of a dominant narrator. Memory \& Cognition, 34(4), 752-762. https://doi.org/10.3758/bf03193423

Drivdahl, S. B. ve Zaragoza, M. S. (2001). The role of perceptual elaboration and individual differences in the creation of false memories for suggested events. Applied Cognitive Psychology, 15(3), 265281. https://doi.org/10.1002/acp.701

Echterhoff, G., Higgins, E. T. ve Levine, J. M. (2009). Shared reality: Experiencing commonality with others' inner states about the world. Perspectives on Psychological Science, 4(5), 496-521. https:// doi.org/10.1111/j.1745-6924.2009.01161.x

Er, N. (2003). A new flashbulb memory model applied to the Marmara earthquake. Applied Cognitive Psychology, 17, 503-517. https://doi.org/10.1002/acp.870

Er, N., Alpar, G. ve Uçar, F. (2005). Görgü tanığının bellek yanılsamaları ve güven kararları: Bağımsız bellek bildirimlerinden sonraki test ve soru turu değişkenlerinin etkisi. Türk Psikoloji Dergisi, 20(56), 45-60.

Fenn, K. M., Griffin, N. R., Uitvlugt, M. G. ve Ravizza, S. M. (2014). The effect of Twitter exposure on false memory formation. Psychonomic Bulletin \& Review, 21(6), 1551-1556. https://doi. org/10.3758/s13423-014-0639-9

French, L., Garry, M. ve Mori, K. (2008). You say tomato? Collaborative remembering leads to more false memories for intimate couples than for strangers. Memory, 16(3), 262-273. https://doi. org/10.1080/09658210701801491

Gabbert, F., Memon, A. ve Allan, K. (2003). Memory conformity: Can eyewitnesses influence each other's memories for an event?. Applied Cognitive Psychology, 17(5), 533-543. https://doi. org/10.1002/acp.885

Gabbert, F., Memon, A., Allan, K. ve Wright, D. B. (2004). Say it to my face: Examining the effects of socially encountered misinformation. Legal and Criminological Psychology, 9(2), 215-227. https:// doi.org/10.1348/1355325041719428

Halbwachs, M. (1950/1980). The collective memory. New York: Harper Colophon Books.

Harris, C.B., Paterson, H.M. ve Kemp, R.I. (2008). Collaborative recall and collective memory: What happens when we remember together? Memory, 16(3), 213-230. https://doi. org/10.1080/09658210701811862

Harris, C. B., Barnier, A. J., Sutton, J. ve Keil, P. G. (2010). How did you feel when "The Crocodile Hunter" died? Voicing and silencing in conversation influences memory for an autobiographical event. Memory, 18(2), 185-197. https://doi.org/10.1080/09658210903153915

Harris, C. B., Barnier, A. J. ve Sutton, J. (2013). Shared encoding and the costs and benefits of collaborative recall. Journal of Experimental Psychology: Learning, Memory, and Cognition, 39(1), 183-195. https://doi.org/10.1037/a0028906

Henkel, L. A. (2014). Point-and-shoot memories the influence of taking photos on memory for a museum tour. Psychological Science, 25(2), 396-402. https://doi.org/10.1177/0956797613504438

Hirst, W. ve Coman, A. (2018). Building a collective memory: The case for collective forgetting. Current Opinion in Psychology, 23, 88-92. https://doi.org/10.1016/j.copsyc.2018.02.002

Hirst, W. ve Echterhoff, G. (2008). Creating shared memories in conversation: Toward a psychology of collective memory. Social Research, 75(1), 183-216. 
Hirst, W. ve Echterhoff, G. (2012). Remembering in conversations: The social sharing and reshaping of memories. Annual Review of Psychology, 63, 55-79. https://doi.org/10.1146/annurevpsych-120710-100340

Hirst, W. ve Manier, D. (2008). Towards a psychology of collective memory. Memory, 16(3), 183-200. https://doi.org/10.1080/09658210701811912

Hirst, W., Manier, D. ve Cuc, A. (2003). The construction of a collective memory. B. Kokinov ve W. Hirst (Ed.), Constructive memory içinde (s. 111-116). Sofya: New Bulgarian University.

Hirst, W., Phelps, E. A., Buckner, R. L., Budson, A. E., Cuc, A., Gabrieli, J. D., ... ve Meksin, R. (2009). Long-term memory for the terrorist attack of September 11: Flashbulb memories, event memories, and the factors that influence their retention. Journal of Experimental Psychology: General, 138, 161-176. https://doi.org/10.1037/a0015527

Irwin-Zarecka, I. (1994). Frames of remembrance: The dynamics of collective memory. New Brunswick: Transaction. https://doi.org/10.4324/9780203791592

Kensinger, E. A., Choi, H. Y., Murray, B. D. ve Rajaram, S. (2016). How social interactions affect emotional memory accuracy: Evidence from collaborative retrieval and social contagion paradigms. Memory \& Cognition, 44(5), 706-716. https://doi.org/10.3758/s13421-016-0597-8

Koppel, J., Wohl, D., Meksin, R. ve Hirst, W. (2014). The effect of listening to others remember on subsequent memory: The roles of expertise and trust in socially shared retrieval-induced forgetting and social contagion. Social Cognition, 32(2), 148-180. https://doi.org/10.1521/soco.2014.32.2.148

Koriat, A., Goldsmith, M. ve Pansky, A. (2000). Toward a psychology of memory accuracy. Annual Review of Psychology, 51(1), 481-537. 1. https://doi.org/10.1146/annurev.psych.51.1.481

Lewandowsky, S., Ecker, U. K., Seifert, C. M., Schwarz, N. ve Cook, J. (2012). Misinformation and its correction: Continued influence and successful debiasing. Psychological Science in the Public Interest, 13(3), 106-131. https://doi.org/10.1177/1529100612451018

Lewandowsky, S., Stritzke, W. G., Freund, A. M., Oberauer, K. ve Krueger, J. I. (2013). Misinformation, disinformation, and violent conflict: From Iraq and the "War on Terror" to future threats to peace. American Psychologist, 68(7), 487-501. https://doi.org/10.1037/a0034515

Li, H. ve Sakamoto, Y. (2014). Social impacts in social media: An examination of perceived truthfulness and sharing of information. Computers in Human Behavior, 41, 278-287. https://doi. org/10.4018/978-1-4666-9518-4.les2

Loftus, E. F., Miller, D. G. ve Burns, H. J. (1978). Semantic integration of verbal information into a visual memory. Journal of Experimental Psychology: Human Learning and Memory, 4(1), 19-31. https://doi.org/10.1037/0278-7393.4.1.19

Loftus, E. F. ve Palmer, J. C. (1974). Reconstruction of automobile destruction: An example of the interaction between language and memory. Journal of Verbal Learning and Verbal Behavior, 13, 585-589. https://doi.org/10.1016/s0022-5371(74)80011-3

Loftus, E. F. ve Zanni, G. (1975). Eyewitness testimony: The influence of the wording of a question. Bulletin of the Psychonomic Society, 5, 86-88. https://doi.org/10.3758/bf03336715

Marsh, R., Cook, G. ve Hicks, J. (2006). Gender and orientation stereotypes bias source-monitoring attributions. Memory, 14(2), 148-160. https://doi.org/10.1080/09658210544000015

Marsh, E. J. ve Rajaram, S. (2019). The digital expansion of the mind: Implications of Internet usage for memory and cognition. Journal of Applied Research in Memory and Cognition, 8(1), 1-14. https:// doi.org/10.1016/j.jarmac.2018.11.001

Meade, M. L., Nokes, T. J. ve Morrow, D. G. (2009). Expertise promotes facilitation on a collaborative memory task. Memory, 17(1), 39-48. https://doi.org/10.1080/09658210802524240 
Meade, M. L. ve Roediger, H. L. (2002). Explorations in the social contagion of memory. Memory \& Cognition, 30, 995-1009. https://doi.org/10.3758/bf03194318

Mısırlısoy, M. ve Ceylan, S. (2014). Olay sonrası yanlış bilgi paradigması: Yaşlanma ve stresin etkisi. Türk Psikoloji Yazıları, 17(33), 60-73.

Mitchell, K. J. ve Zaragoza, M. S. (1996). Repeated exposure to suggestion and false memory: The role of contextual variability. Journal of Memory and Language, 35(2), 246-260. https://doi. org/10.1006/jmla.1996.0014

Mitchell, K. J. ve Zaragoza, M. S. (2001). Contextual overlap and eyewitness suggestibility. Memory \& Cognition, 29(4), 616-626. https://doi.org/10.3758/bf03200462

Muller, F., Bermejo, F. ve Hirst, W. (2016). Argentines' collective memories of the military Junta of 1976: Differences and similarities across generations and ideology. Memory, 24(7), 990-1006. https://doi.org/10.1080/09658211.2015.1061013

Muller, F., Bermejo, F. ve Hirst, W. (2018). Cultural and communicative memories: Contrasting Argentina's 1976 coup d'état and the 2001 economic-political-social crisis. Memory, 26(7), 974984. https://doi.org/10.1080/09658211.2018.1431283

Mutlutürk, A., Boduroğlu, A. ve Tekcan, A. İ. (2018). Kişisel ve toplumsal bellek. S. Gülgöz, S. Öner ve B. Ece Uslu (Ed.), Hayatı hatırlamak: Otobiyografik belleğe bilimsel yaklaşımlar (s. 111-116). İstanbul: Koç Üniversitesi Yayınları

Novick, P. (1999). The Holocaust in American life. Boston: Houghton Mifflin Company. https://doi. org/10.1086/ahr/106.2.534

Olick, J. K. (1999). Collective memory: The two cultures. Sociological Theory, 17, 333-348. https://doi. org/10.1111/0735-2751.00083

Olick, J. K. ve Robbins, J. (1998). Social memory studies: From "collective memory" to the historical sociology of mnemonic practices. Annual Review of Sociology, 24(1), 105-140. https://doi. org/10.1146/annurev.soc.24.1.105

Ost, J., Vrij, A., Costall, A. ve Bull, R. (2002). Crashing memories and reality monitoring: Distinguishing between perceptions, imaginations and 'false memories'. Applied Cognitive Psychology, 16(2), 125-134. https://doi.org/10.1002/acp.779

Páez, D., Bellelli, G. ve Rimé, B. (2009). Flashbulb Memories, Culture and Collective Memories: Psychosocial processes related to rituals, emotions, and memories. O. Luminet ve A. Curci (Ed.). Flashbulb Memories: New Issues and New Perspectives içinde (s. 227-246). Hove and New York: Psychology Press.

Páez, D. ve Liu, J. (2010). Collective memory of conflicts. D. Bar-Tal (Ed.) Intergroup conflicts and their resolution: Social psychological perspective içinde (s. 105-124). Hove and New York: Psychology Press.

Peker, M. ve Tekcan, A. İ. (2009). The role of familiarity among group members in collaborative inhibition and social contagion. Social Psychology, 40, 111-118. https://doi.org/10.1027/1864-9335.40.3.111

Pereira-Pasarin, L. P. ve Rajaram, S. (2011). Study repetition and divided attention: Effects of encoding manipulations on collaborative inhibition in group recall. Memory \& Cognition, 39(6), 968-976. https://doi.org/10.3758/s13421-011-0087-y

Pezdek, K. (2003). Event memory and autobiographical memory for the events of September 11, 2001. Applied Cognitive Psychology, 17, 1033-1045. https://doi.org/10.1002/acp.984

Rajaram, S. ve Pereira-Pasarin, L. P. (2007). Collaboration can improve individual recognition memory: Evidence from immediate and delayed tests. Psychonomic Bulletin \& Review, 14(1), 95100. https://doi.org/10.3758/bf03194034 
Roediger III, H. L. ve Abel, M. (2015). Collective memory: A new arena of cognitive study. Trends in Cognitive Sciences, 19(7), 359-361. https://doi.org/10.1016/j.tics.2015.04.003

Roediger III, H. L. ve McDermott, K. B. (1995). Creating false memories: Remembering words not presented in lists. Journal of Experimental Psychology: Learning, Memory, and Cognition, 21(4), 803-814. https://doi.org/10.1037/0278-7393.21.4.803

Roediger III, H. L., Meade, M. L. ve Bergman, E. (2001). Social contagion of memory. Psychonomic Bulletin and Review, 8, 365-71. https://doi.org/10.3758/bf03196174

Roediger III, H. L., Zaromb, F. M. ve Butler, A. C. (2009). The role of repeated retrieval in shaping collective memory. P. Boyer ve J. Wertsch (Ed.). Memory in mind and culture içinde (s. 29-58.). New York: Cambridge University Press. https://doi.org/10.1017/cbo9780511626999.009

Schuman, H., Akiyama, H. ve Knauper, B. (1998). Collective memories of Germans and Japanese about the past half-century. Memory, 6(4), 427-454. https://doi.org/10.1080/741942611

Schuman, H. ve Rodgers, W. L. (2004). Cohorts, chronology, and collective memories. Public Opinion Quarterly, 68(2), 217-254. https://doi.org/10.1093/poq/nfh012

Schuman, H. ve Scott, J. (1989). Generations and collective memories. American Sociological Review, 54(3), 359-381. https://doi.org/10.2307/2095611

Sparrow, B., Liu, J. ve Wegner, D. M. (2011). Google effects on memory: Cognitive consequences of having information at our fingertips. Science, 333(6043), 776-778. https://doi.org/10.1126/ science. 1207745

Stone, C. B., Coman, A., Brown, A. D., Koppel, J. ve Hirst, W. (2012). Toward a science of silence: The consequences of leaving a memory unsaid. Perspectives on Psychological Science, 7(1), 39-53. https://doi.org/10.1177/1745691611427303

Stone, C. B. ve Jay, A. C. (2019). From the individual to the collective: The emergence of a psychological approach to collective memory. Applied Cognitive Psychology, 33(4), 504-515. https://doi. org/10.1002/acp.3564

Surprenant, A. M. ve Neath, I. (2009). Principles of memory. New York: Psychology Press. https://doi. org/10.1177/1750698010392131

Svob, C., Brown, N. R., Reddon, J. R., Uzer, T. ve Lee, P. J. (2014). The transitional impact scale: Assessing the material and psychological impact of life transitions. Behavior Research Methods, 46(2), 448-455. https://doi.org/10.3758/s13428-013-0378-2

Tekcan, A. İ., Boduroglu, A., Mutlutürk, A. ve Erciyes, A. A. (2017). Life-span retrieval of public events: Reminiscence bump for high-impact events, recency for others. Memory \& Cognition, 45(7), 1095-1112. https://doi.org/10.3758/s13421-017-0724-1

Tekcan, A. I., Ece, B., Gülgöz, S. ve Er, N. (2003). Autobiographical and event memory for 9/11: Changes across one year. Applied Cognitive Psychology, 17, 1057-1066. https://doi.org/10.1002/acp.985

Walther E, Bless H, Strack F, Rackstraw P, Wagner D ve Werth L. (2002). Conformity effects in memory as a function of group size, dissenters and uncertainty. Applied Cognitive Psychology, 16, 793-810. https://doi.org/10.1002/acp.828

Wang, Q. (2019). The individual mind in the active construction of its digital niche. Journal of Applied Research in Memory and Cognition, 8(1), 25-28. https://doi.org/10.1016/j.jarmac.2018.12.005

Wang, Q. ve Aydin, Ç. (2009). Cultural issues in flashbulb memory. O. Luminet ve A. Curci (Ed.), Flashbulb memories içinde (s. 247-268). New York: Psychology Press.

Weldon, M. S. ve Bellinger, K. D. (1997). Collective memory: Collaborative and individual processes in remembering. Journal of Experimental Psychology: Learning, Memory and Cognition, 23, 11601175. https://doi.org/10.1037/0278-7393.23.5.1160 
Wertsch, J. V. (2002). Voices of collective remembering. New York: Cambridge University Press. https://doi.org/10.1017/cbo9780511613715

Wertsch, J. V. ve Roediger, H. L. (2008). Collective memory: Conceptual foundations and theoretical approaches. Memory, 16(3), 318-326. https://doi.org/10.1080/09658210701801434

Yamashiro, J. (2017). Convergence on collective memories: Central speakers and distributed remembering (Yayınlanmamış Doktora Tezi). The New School for Social Research of The New School University, New York.

Yardi, S. ve Boyd, D. (2010). Dynamic debates: An analysis of group polarization over time on twitter. Bulletin of Science, Technology \& Society, 30(5), 316-327. https://doi. org $/ 10.1177 / 0270467610380011$

Yaron-Antar, A. ve Nachson, I. (2006). Collaborative remembering of emotional events: The case of Rabin's assassination. Memory, 14(1), 46-56. https://doi.org/10.1080/09658210444000502

Zaragoza, M. S. ve Mitchell, K. J. (1996). Repeated exposure to suggestion and the creation of false memories. Psychological Science, 7(5), 294-300. https://doi.org/10.1111/j.1467-9280.1996. tb00377.x 